Article

\title{
Neutral Low-Dimensional Assemblies of a Mn(III) Schiff Base Complex and Octacyanotungstate(V): Synthesis, Characterization, and Magnetic Properties
}

\author{
Anna M. Majcher ${ }^{1}$, Guillaume Pilet ${ }^{2}$, Vladimir S. Mironov ${ }^{3}$ and Kira E. Vostrikova ${ }^{4, *}$ \\ 1 Institute of Physics, Jagiellonian University, Lojasiewicza 11, PL-30348 Krakow, Poland; \\ anna.majcher@uj.edu.pl \\ 2 Laboratoire des Multimatériaux et Interfaces (UMR 5615), Université Claude Bernard Lyon 1, \\ 69622 Villeurbanne Cedex, France; guillaume.pilet@univ-lyon1.fr \\ 3 Shubnikov Institute of Crystallography of Federal Scientific Research Centre "Crystallography and \\ Photonics" RAS, Leninsky prospect 59, 119333 Moscow, Russia; mirsa@list.ru \\ 4 Nikolaev Institute of Inorganic Chemistry SB RAS, Lavrentiev Avenue 3, 630090 Novosibirsk, Russia \\ * Correspondence: vosk@niic.nsc.ru; Tel.: +7-383-3165845
}

Academic Editor: Coen de Graaf

Received: 1 February 2017; Accepted: 17 March 2017; Published: 24 March 2017

\begin{abstract}
Two novel low-dimensional molecular magnetic materials were prepared by the self-assembly of $3 \mathrm{~d}$ - and $5 \mathrm{~d}$-metal complexes. These are the first neutral heterobimetallic cyanobridged compounds involving one anisotropic Mn(III) Schiff base complex and one octacyanotungstate $(\mathrm{V})$ per molecular unit. A slow diffusion of the constituents' solutions leads to the formation of the $0 \mathrm{D}$ crystalline complex 1 , due to coordination of a water molecule to the $\mathrm{Mn}$ center, which prevents polymer formation. A rapid mixing of reagents results in the precipitation of the microcrystalline powder of complex $\mathbf{2}$, which based on the totality of experimental data, possesses a 1D polymeric structure. The magnetic studies have shown that antiferromagnetic exchange interactions prevail in $\mathbf{1}\left(J / k_{\mathrm{B}}=-13.1(7) \mathrm{K}, D=-3.0(1.3) \mathrm{K}, z J^{\prime}=-0.16(20) \mathrm{K}\right.$ and $\left.g_{a v}=2.00(1)\right)$; while the presence of the significant intramolecular $\mathrm{Mn}(\mathrm{III})-\mathrm{W}(\mathrm{V})$ ferromagnetic coupling through cyanide bridge is characteristic for $2\left(J / k_{\mathrm{B}}=46.1(5) \mathrm{K}, g_{\mathrm{Mn}}=2.11(3)\right.$, fixed $\left.g_{\mathrm{W}}=2.0\right)$. Due to the weak interchain interactions, $z J^{\prime} / k_{\mathrm{B}}=-0.8(2) \mathrm{K}$, and compound 2 is a metamagnet with the Néel temperature of $9.5 \mathrm{~K}$ undergoing a spin-flip transition at $2 \mathrm{kOe}$. The slow magnetization dynamics of 2 were investigated at a DC field of 0 and $2 \mathrm{kOe}$, giving the values of $\tau_{0} 32(15)$ and 36(15) ps, respectively, well within the range typical for single-chain magnets (SCMs). The respective $\Delta_{\tau} / k_{\mathrm{B}}$ values were 48.4(1.2) and 44.9(1.0) K.
\end{abstract}

Keywords: cyanide-bridged heterometallic assemblies; octacyanotungstate(V); Mn(III) Schiff base complexes; single-chain magnet; 1D coordination polymers; metamagnet; ferromagnetic coupling

\section{Introduction}

Molecular magnets of low dimensionality represent polynuclear coordination compounds in which the paramagnetic ions linked together via bridging ligands are particularly interesting due to the slow magnetic relaxation that a large group among them exhibit. What makes them especially attractive is the fact that they are very likely to find applications in high-density data storage or quantum computers [1-4]. A key parameter for describing these materials is the anisotropy energy barrier, $\Delta_{A}$, which needs to be overcome to reverse the magnetization.

For the zero-dimensional (0D) systems named single-molecule magnets (SMMs), the $\Delta_{A}$ value depends on the total spin and the energy of uniaxial anisotropy of the molecule and can be expressed as $\Delta_{A}=S^{2}|D|$ for the integer $S$ and $\left(S^{2}-1 / 4\right)|D|$ for the half-integer $S$ [4], where the axial zero-field 
splitting parameter $D<0$. In order to use the SMMs in real devices or at least in their prototypes, the $\Delta_{A}$ should be high enough to fix the magnetic moment orientation and to prevent quantum tunneling. Slow magnetic relaxation has also been found for one-dimensional (1D) coordination compounds, known as single chain magnets (SCMs) [5-27]. In terms of greater relaxation barriers, SCMs possess an advantage over SMMs. This benefit originates from an additional contribution in $\Delta_{A}$, yclept correlation energy $\Delta_{\xi}$, which is provided by the exchange coupling $(J)$ between the paramagnetic centers. Taking into account that an interaction between adjacent spin carriers is $-2 J S_{1} \cdot S_{2}, \Delta_{\xi}=4|J| S^{2}$ for an isotropic model when $|D / J|>4 / 3$ (Ising limit), while when $|D|<<|J|, \Delta_{\xi}=4 S^{2}|J D|^{1 / 2}$ (Heisenberg limit) [2,7]. Therefore, for an infinite magnetic chain the total spin reversal barrier can be written as $U_{\text {eff }}=\Delta_{A}+2 \Delta_{\xi}$ [28-30]. However, in a finite-length spin chain, the contribution of the correlation energy to the $U_{\text {eff }}$ is twice as small $\left(U_{\text {eff }}=\Delta_{A}+\Delta_{\xi}\right)$ due to a nucleation effect of the chain ends. Indeed, at low temperatures the relaxation dynamics of SCMs are typically described by the finite-length model [11].

Cyano-bridged metal assemblies have provided a large number of compounds with SMM [31-38] and SCM behaviors [39-48]. The larger part of these materials comprise $3 \mathrm{~d}$ metal ions as the core magnetic units. This can be explained by the fact that compared to their $4 \mathrm{~d}$ and $5 \mathrm{~d}$ congeners, the coordination chemistry of the first row transition metal complexes is well studied, and there are numerous theoretical models to describe their magnetic behavior. The use of heavier transition metal complexes in the design of low-dimensional nanomagnets has a few advantages. First of all, they possess more diffuse valence orbitals than $3 \mathrm{~d}$ metals that can offer stronger magnetic exchange interactions [32]. These ions are also found to exist in a variety of oxidation states. The facile changes in oxidation states and the ability to promote these changes via external stimuli, for example by the use of light, to trigger charge transfer reactions, has attracted attention of researchers in the area of multifunctional materials and has produced numerous compounds with several intriguing physical properties, such as photomagnetism [49-51].

Compounds involving cyanide complexes as metalloligands are the most common in the area of $4 \mathrm{~d}$ and 5d molecular magnetism [32], the majority of which are cyanobridged heterometallic assemblies including the octacyanometallates [50-52]. Some of them are 1D polymers [53-56]; others possess layered [57-63] or 3D network structures [64-68]. The paramagnetic cyanotungstate(V) tectones have been used to build discrete molecules [69-71], chains [53-56], 2D [57] and 3D networks [64-68], and some of them have displayed variable magnetic properties such as high ordering temperatures [72], photo-induced magnetism [73,74], SMMs [75], and SCMs [17,54,55]. However, the assemblies of the paramagnetic $\left[\mathrm{W}(\mathrm{CN})_{8}\right]^{3-}$ precursor and manganese(III) Schiff base complex, $[\mathrm{Mn}(\mathrm{SB})]^{+}$, are fairly limited and poorly studied in comparison with the large family of bimetallic compounds comprised of the $[\mathrm{Mn}(\mathrm{SB})]^{+}$cation and the $3 \mathrm{~d}$ metal hexacyanides that are extensively investigated both structurally and magnetically [76]. To the best of our knowledge, so far only six bimetallic low-dimensional magnetic systems involving $[\mathrm{Mn}(\mathrm{SB})]^{+}$and $\left[\mathrm{W}(\mathrm{CN})_{8}\right]^{3-}$ units have been reported $[54,55,69-71,77]$.

To compensate for the triple charge of the $\left[\mathrm{W}^{\mathrm{V}}(\mathrm{CN})_{8}\right]^{3-}$ unit, three $[\mathrm{Mn}(\mathrm{SB})]^{+}$moieties are needed. Thus, the nuclearity of molecular $\{\mathrm{MnW}\}$ species varies depending on the structure of the SB-ligand. In comparison with acacen ${ }^{2-}$ (N,N-ethylenebis(acetylacetonylideneiminato)) included in the layered complex $\mathrm{K}[\mathrm{Mn} \text { (acacen) }]_{2}\left[\mathrm{~W}(\mathrm{CN})_{8}\right] \cdot 2 \mathrm{H}_{2} \mathrm{O}$ [57], the salen-type ligands are too large to be assembled through the three cyano bridges in a tetranuclear neutral moiety $[\mathrm{Mn}(\mathrm{SB})]_{3}\left[\mathrm{~W}(\mathrm{CN})_{8}\right]$. Even in the case of the smallest di-anion ligand, salen ${ }^{2-}\left(\mathrm{N}, \mathrm{N}^{\prime}\right.$-ethylenebis(salicylideneiminato)), only two $\mathrm{Mn}^{\mathrm{III}}$-centers in $\left[\mathrm{Mn}(\right.$ salen $) \mathrm{H}_{2} \mathrm{O}_{3}\left[\mathrm{~W}(\mathrm{CN})_{8}\right][70]$ are bound directly to the cyanometallate unit and the third one is phenolate-bridged to the $\{\mathrm{W}-\mathrm{CN}-\mathrm{Mn}$ (salen) $\}$ unit forming an $\mathrm{Mn}-\mathrm{NC}-\mathrm{W}-\mathrm{CN}-\mathrm{Mn}-\mathrm{O}_{\mathrm{PheO}}-\mathrm{Mn}$ skeleton. Two closely related tri-nuclear compounds: $\left[\mathrm{Mn}\left({ }^{5 \mathrm{Cl}}\right.\right.$ salmen $\left.)\left(\mathrm{H}_{2} \mathrm{O}\right)_{2}\right]\left\{\left[\mathrm{Mn}\left({ }^{5 \mathrm{Cl}} \mathrm{salmen} \mathrm{H}_{2} \mathrm{O}\right]_{2} \mathrm{~W}(\mathrm{CN})_{8}\right]\right\}$ $\left({ }^{5 \mathrm{Cl}}\right.$ salmen $^{2-}=\mathrm{N}, \mathrm{N}^{\prime}-(1-$ methyl-ethylenebis(5-chlorosalicylideneiminato $\left.)\right)$ [77] and [ $\mathrm{Mn}^{5}\left({ }^{5 \mathrm{Cl}} \mathrm{saltmen}_{\mathrm{t}}\right) \mathrm{H}_{2} \mathrm{O}$

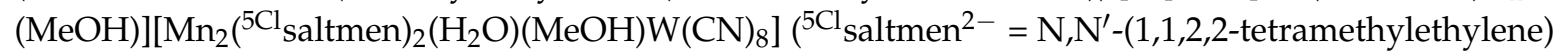
bis(5-chlorosalicylideneiminato) $[71]$ have a separated $\left[\mathrm{Mn}\left({ }^{5 \mathrm{Cl}} \mathrm{SB}\right)(\mathrm{Solv})^{2}\right]^{+}$cation, while in the binuclear

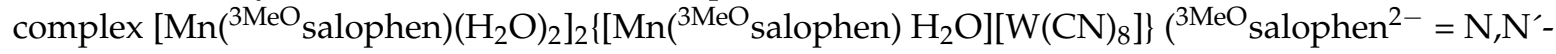


phenylenebis(3-methoxysalicylidene-iminato)) [69] the hydrogen bonds between aqua ligands as well as $\pi-\pi$ contacts between aromatic rings bind the neighboring $\left\{\mathrm{Mn}^{\mathrm{III}} \mathrm{W}^{\mathrm{V}}\right\}^{2-}$ dimer and isolated $\mathrm{Mn}^{\mathrm{III}}$ moiety. Both SCMs known to date, involving $\left[\mathrm{W}^{\mathrm{V}}(\mathrm{CN})_{8}\right]^{3-}:\left[\mathrm{Mn}\left({ }^{5 \mathrm{Br}}\right.\right.$ salen $\left.\left.)\left(\mathrm{H}_{2} \mathrm{O}\right)_{2}\right]\left\{\left[\mathrm{Mn}\left({ }^{5 \mathrm{Br}} \text { salen }\right) \mathrm{H}_{2} \mathrm{O}\right]_{2} \mathrm{~W}(\mathrm{CN})_{8}\right]\right\}$ $\left({ }^{5 B r}\right.$ salen $^{2-}=\mathrm{N}, \mathrm{N}^{\prime}$-ethylenebis(5-bromosalicylideneiminato)) and $\left[\mathrm{Mn}(\mathrm{L})\left(\mathrm{H}_{2} \mathrm{O}\right)_{2}\right]_{2}\left[\mathrm{Mn}(\mathrm{L}) \mathrm{W}(\mathrm{CN})_{8}\right]$, $\mathrm{H}_{2} \mathrm{~L}=\mathrm{N}, \mathrm{N}^{\prime}$-bis(2-hydroxynaphthalene-1-carbaldehydene)-1,3-diamino propane) [55], also comprise a separated $\left[\mathrm{Mn}(\mathrm{SB})\left(\mathrm{H}_{2} \mathrm{O}\right)_{2}\right]^{+}$counter ion, dimerized or not.

On account of a great variety of self-assembling in the $\left[\mathrm{Mn}(\mathrm{SB}) \mathrm{H}_{2} \mathrm{O}\right]^{+} /\left[\mathrm{W}(\mathrm{CN})_{8}\right]^{3-}$ system, the rational design of the low-D magnetic materials is not possible due to a random localization of both the bridged and separated paramagnetic anisotropic units of $\left[\mathrm{Mn}{ }^{\mathrm{III}}(\mathrm{SB})\left(\mathrm{H}_{2} \mathrm{O}\right)_{2}\right]^{+}$in the crystals of the heterobimetallic complexes. The main tactic for a telic synthesis of 0-1D species is the preparation of the neutral $\mathrm{Mn}^{\mathrm{III}} \mathrm{W}^{\mathrm{V}}$ magnetic assemblies. To implement this objective, once charged heteroligand cyanide species $\left[\mathrm{WL}(\mathrm{CN})_{6}\right]^{-}(\mathrm{L}=$ bipyridine or phenantroline) have been used [78-81]. Despite the successful synthesis of the few $[\mathrm{Mn}(\mathrm{SB})]\left[\mathrm{WL}(\mathrm{CN})_{6}\right]$ compounds with SCM behavior, this method has an essential drawback because the yield of octacoordinated $\left[\mathrm{WL}(\mathrm{CN})_{6}\right]^{-}$precursors is low [80]. Very recently, the neutral molecular dimeric complexes were studied [82], as well as a row of chain coordination polymers [48] comprised of $3 \mathrm{~d}$ metal cyanides, $\left[\mathrm{M}^{\mathrm{III}}(\mathrm{CN})_{6}\right]^{3-}$, and a triple charged $\left[\mathrm{Mn}^{\mathrm{III}}\left(\mathrm{SB}^{2+}\right)\right]^{3+}$-unit presented in Scheme 1. This choice was driven by the following factors: (i) the $\mathrm{Mn}^{\mathrm{III}}$ unit with a total " $3+$ " charge can provide an assembling of neutral $\left\{\mathrm{Mn}^{\mathrm{III}} \mathrm{SB}\right\} /\left\{\mathrm{M}^{\mathrm{III}}(\mathrm{CN})_{6}\right\}$ 1:1 complexes due to electrostatic attraction; (ii) the large $\left(\mathrm{CH}_{3}\right)_{3} \mathrm{~N}^{+}$groups of the 5TMAMsalen ligand should contribute to an axial coordination of the $[\mathrm{Mn}(5 \mathrm{TMAMsalen})]^{3+}$ cations to the $\left[\mathrm{M}^{\mathrm{III}}(\mathrm{CN})_{6}\right]^{3-}$ anion and (iii) to cancel or reduce the interchain magnetic interactions through the joint impact of both charge repulsion and steric hindrance, leading to spatial separation of the final 1D-polymer chains [48].

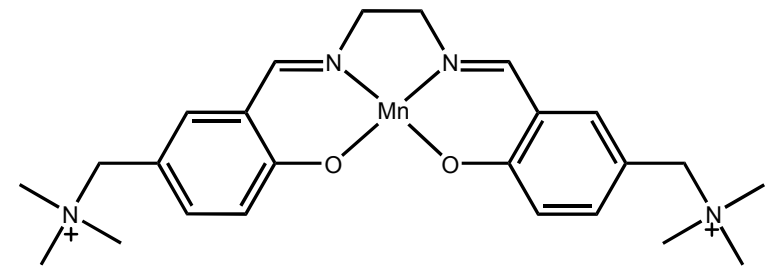

Scheme 1. Triple charged unit $\left[\mathrm{Mn}^{\mathrm{III}}\left(\mathrm{SB}^{2+}\right)\right]^{3+}$.

In the present report, we have extended this approach to the synthesis of a dinuclear complex [Mn $\left.{ }^{\mathrm{III}}(5 \mathrm{TMAMsalen})\left(\mathrm{H}_{2} \mathrm{O}\right) \mathrm{W}^{\mathrm{V}}(\mathrm{CN})_{8}\right]\left(\mathrm{H}_{2} \mathrm{O}\right)_{4.75} \mathrm{CH}_{3} \mathrm{CN}(\mathbf{1})$ and a coordination chain polymer $\left[\mathrm{Mn}^{\mathrm{III}}\right.$ (5TMAMsalen) $\left.\mathrm{W}^{\mathrm{V}}(\mathrm{CN})_{8}\right]\left(\mathrm{H}_{2} \mathrm{O}\right)_{8} \mathrm{CH}_{3} \mathrm{CN}$ (2) composed of equally charged constituents. The compounds were characterized by infra red spectroscopy (IR), thermogravimetric analysis (TG), X-ray diffraction (XRD), and elemental analysis. The detailed magnetic measurements were performed for both complexes. An explicit analysis of the magnetic properties together with a set of the other studies has revealed that $\mathbf{2}$ is a metamagnetic chain compound exhibiting a slow relaxation of magnetization.

\section{Results and Discussion}

\subsection{Preparation and Characterization}

It is very important to underline that the compounds were synthesized using a stoichiometric 1:1 molar ratio of the constituents by the reaction of acetonitrile solution of [Mn(5TMAMsalen $)\left(\mathrm{H}_{2} \mathrm{O}\right)_{2}$ ] $\left(\mathrm{ClO}_{4}\right)_{3}\left(\mathrm{H}_{2} \mathrm{O}\right)$ with aqueous $\mathrm{K}_{3}\left[\mathrm{~W}(\mathrm{CN})_{8}\right]\left(\mathrm{H}_{2} \mathrm{O}\right)_{2}$. A diffusion method was performed for $\mathbf{1}$, while a direct mixing of the precursor solutions, followed by heating, for 2 . The latter can also be obtained starting from 1 (See experimental section). The diffusion route produces 1 in the form of long brown-yellowish parallelepiped-like batons in a high yield, while the precipitation route results in a dark brown-reddish powder with a quantitative yield. The interdiffusion of aqueous and acetonitrile 
solutions produces the binuclear complex due to the coordination of an aqua-ligand to the Mn end of the $\{\mathrm{W}-\mathrm{Mn}\}$ unit. Therefore, to avoid this process it is necessary to use the non-coordinating solvents along with the assembling of the chain polymer $\left[\mathrm{Mn}(\mathrm{SB}) \mathrm{W}(\mathrm{CN})_{8}\right]_{n}$. However, all of our attempts to grow the single crystals of the 1D material using dry nitromethane and dichloromethane (or chloroform) as solvents for the Mn- and W-precursors, respectively, failed. If in the case of layering, for all solvent combinations, an impenetrable membrane was formed on the interface between the two solutions that prevented further contacts of the components, then direct mixing has resulted in amorphous powders. Very often, these powders were contaminated by products containing perchlorate anions, registered by IR.

At room temperature during the period of a few weeks, the enclosed in a vial crystals of $\mathbf{1}$ partially lost the solvate water molecules but kept their crystallinity without deterioration of the X-ray diffraction quality. Both 1 and 2 gradually lose solvent molecules during storage and heating. A thermo-analytical investigation of $\mathbf{1}$ has shown that in the temperature range of $25-145{ }^{\circ} \mathrm{C}$, the solvent loss of about $13.5 \%\left(12.87 \%\right.$ calculated for [Mn(5TMAMsalen) $\left.\left.\left(\mathrm{H}_{2} \mathrm{O}\right)\right]\left[\mathrm{W}(\mathrm{CN})_{8}\right]\left(\mathrm{H}_{2} \mathrm{O}\right)_{4.75}\left(\mathrm{CH}_{3} \mathrm{CN}\right)\right)$ occurs in two steps. The first step (about $11.5 \%$ ) most likely corresponds to the evaporation of four non-coordinated solvents: water molecules and one $\mathrm{CH}_{3} \mathrm{CN}$ molecule, while the second step (about $2 \%$ ) is caused by a release of the coordinated $\mathrm{H}_{2} \mathrm{O}$ (See Figure $\mathrm{S} 1$ of the Supplementary information (SI)).

The powder samples of $\mathbf{2}$, depending on their dispersity, lose solvent molecules with a different speed. For this reason, the solvent content in $\mathbf{2}$ was determined by heating a part of the freshly prepared sample under vacuum at $110{ }^{\circ} \mathrm{C}$ up to a constant sample weight, wherein the weight loss was $17 \%$. A sample treated in this manner as well as its progenitor was analyzed for CHN content. The powders of $\mathbf{2}$ heated in mild conditions absorb some amount of water from the air, which is confirmed by a weight loss step on the TG curve (See Figure S1, SI). An intensive decomposition of the complexes starts above $200^{\circ} \mathrm{C}$. It is noteworthy that $\mathbf{2}$ is somewhat more thermally stable compared to $\mathbf{1}$, which is clearly visible in Figures S1 and S2, where the TG and DTG plots for both complexes are presented. The higher thermal stability of $\mathbf{2}$ is consistent with the polymeric structure.

The compounds have very similar IR spectra in the range of 1700 to $400 \mathrm{~cm}^{-1}$, where the majority of frequencies match the coordinated Schiff base ligand frequencies. The broad absorptions are centered at 3440 and $3417 \mathrm{~cm}^{-1}$ for $\mathbf{1}$ and $\mathbf{2}$, respectively, being more intensive for the latter. Such a broad peak indicates the existence of a system of hydrogen bonds. In the region of 2100 to $2030 \mathrm{~cm}^{-1}$, both complexes have a complicated rake of peaks characteristic for $\mathrm{CN}$ vibration stretches (See Table 1). The presence of a set of bands indicates that the cyanide groups in $\left[\mathrm{W}(\mathrm{CN})_{8}\right]^{3-}$ are partly included in different types of interactions (bridging, hydrogen bonding). Note that for 2 , the majority of $v_{\mathrm{CN}}$ peaks are slightly shifted towards higher frequencies compared to those of $\mathbf{1}$. This may be associated with a more linked character of the $\left[\mathrm{W}(\mathrm{CN})_{8}\right]^{3-}$ metalloligand, which is in favor of the polymeric nature of 2 .

Table 1. Cyanide vibration stretches for 1,2 , and $\left(\mathrm{Bu}_{4} \mathrm{~N}\right)_{3}\left[\mathrm{~W}(\mathrm{CN})_{8}\right]\left(\mathrm{cm}^{-1}\right)$.

\begin{tabular}{ccc}
\hline $\mathbf{1}$ & $\left.\mathbf{( B u}_{\mathbf{4}} \mathbf{N}\right)_{3}\left[\mathbf{W}(\mathbf{C N})_{8}\right][83]$ & $\mathbf{2}$ \\
\hline 2165.7 sh & - & $2167.6 \mathrm{sh}$ \\
2161.8 & - & 2161.8 \\
2138.7 & 2141 & 2146.4 \\
2127.1 & 2130 & $2129.0 \mathrm{sh}$ \\
2121.3 & 2123 & - \\
2100.0 & - & 2111.7 \\
2084.0 & - & 2088.0 \\
2033.0 & - & 2038.4 \\
\hline
\end{tabular}

\subsection{Description of the Molecular Structure}

The crystallographic data and structure refinement summary for $\mathbf{1}$ is included in Table 2. Single crystal X-ray structural analysis has demonstrated that this compound has a $0 \mathrm{D}$ molecular structure 
with an asymmetric unit (Figure 1) representing a neutral bimetallic assembly and consisting of one $\left[\mathrm{W}(\mathrm{CN})_{8}\right]^{3-}$ anion and one $\left[\mathrm{Mn}(5 \mathrm{TMAMsalen})\left(\mathrm{H}_{2} \mathrm{O}\right)\right]^{3+}$ cation. The slightly distorted square antiprism coordination environment of the tungsten ion comprises eight cyanide ligands. Some bond distances and angles defining the coordination polyhedron geometry are shown in Table 2 . The $\mathrm{W}-\mathrm{C}$ bond distances vary from 2.151(7) to 2.168(6) $\AA$ with an average value of 2.156(6) $\AA$ and the W-C-N angles are close to $180^{\circ}$ with the greatest deviation from linearity of $1.58^{\circ}$, which is consistent with the data obtained for the related compounds $[50,57,69,70,77]$. The coordination environment of the Mn ion is an elongated tetragonal bipyramid because of the Jahn-Teller distortion. The $2 \mathrm{O}$ and $2 \mathrm{~N}$ donor atoms of the 5TMAMsalen ligand in the basal plane of the pyramid form shorter bonds of 1.873-1.989 , while one $\mathrm{N}$ atom and an $\mathrm{O}$ atom of an $\mathrm{H}_{2} \mathrm{O}$ molecule in the axial positions form a much longer bond (2.244-2.447 $\AA$ ) (Table 2). The Mn-N-C bond angle is less than $180^{\circ}$ and is equal to $160.8^{\circ}$. Such a flexion is typical for the cyanide bridged $\mathrm{Mn}^{\mathrm{III}}-\mathrm{M}(\mathrm{CN})_{\mathrm{n}}$ complexes $[57,69-71,77,82,84,85]$.

Table 2. Selected bond distances ( $(\AA)$ and angles $\left(^{\circ}\right)$ for $\mathbf{1}$.

\begin{tabular}{cc}
\hline \multicolumn{2}{c}{$[\text { Mn(5TMAMsalmen) }]^{3+}$ Moiety } \\
\hline Mn- $\mathrm{O}_{\text {phenolate }}$ & $1.873(4)$ \\
& $1.895(3)$ \\
\hline Mn- $\mathrm{N}_{\text {imine }}$ & $1.985(4)$ \\
& $1.989(4)$ \\
\hline $\mathrm{Mn}-\mathrm{O}_{\text {water }}$ & $2.247(4)$ \\
$\mathrm{Mn}-\mathrm{N}_{\text {cyanide }}$ & $2.244(4)$ \\
$\mathrm{Mn}-\mathrm{N} \equiv \mathrm{C}$ & $160.8(3)$ \\
$\mathrm{N}_{\text {imine }}-\mathrm{C}-\mathrm{C}-\mathrm{N}_{\text {imine }}$ & $43.3(6)$ \\
\hline$\left[\mathrm{W}(\mathrm{CN})_{8}\right]^{3-}$ Moiety & \\
\hline & $2.154(6)$ \\
& $2.152(5)$ \\
& $2.159(5)$ \\
$\mathrm{M}-\mathrm{C}_{\text {cyanide }}$ & $2.157(6)$ \\
& $2.168(6)$ \\
& $2.152(5)$ \\
& $2.153(6)$ \\
& $2.151(7)$ \\
\hline
\end{tabular}

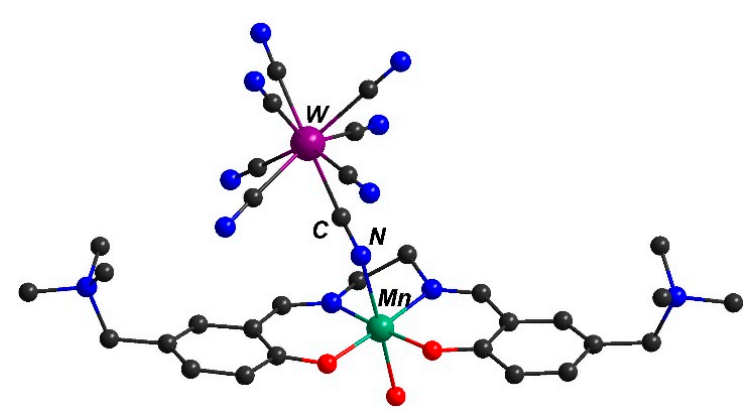

Figure 1. Molecular structure of the $\left[\mathrm{Mn}(5 \mathrm{TMAMsalen})\left(\mathrm{H}_{2} \mathrm{O}\right) \mathrm{W}(\mathrm{CN})_{8}\right]$ unit in 1. Hydrogen atoms are omitted for clarity.

Similar to the case of related 0D [82] and 1D [48] compounds, $\left[\mathrm{Mn}^{\mathrm{IIII}}\left(\mathrm{SB}^{+}\right) \mathrm{M}^{\mathrm{III}}(\mathrm{CN})_{6}\left(\mathrm{H}_{2} \mathrm{O}\right)\right]\left(\mathrm{M}^{\mathrm{III}}=\right.$ $\mathrm{Fe}, \mathrm{Mn}$, and $\mathrm{Cr}$ ), the Schiff-base ligand is in an envelope conformation with a torsion angle comprising the $\mathrm{N}_{\text {imine }}-\mathrm{C}-\mathrm{C}-\mathrm{N}_{\text {imine }}$ core and a dihedral angle between the aromatic rings. In addition, in $\mathbf{1}$ the positively charged triethylammonium groups of the Schiff base ligand are in the cis-position relatively to the $\left[\mathrm{Mn}^{\mathrm{III}} \text { (5TMAMsalen) }\right]^{3+}$ unit plane similarly to its $3 d$-congener described in [82], while in the SCMs reported in [48] these groups are in trans-position. 
The neutral bimetallic units of [Mn(5TMAMsalen) $\left.\left(\mathrm{H}_{2} \mathrm{O}\right) \mathrm{W}(\mathrm{CN})_{8}\right]$ are bound into pairs by the hydrogen bonds between the aqua ligands and phenolate oxygen as well as the $\pi-\pi$ contacts of $3.34 \AA$ between aromatic rings (Figure 2). The distance of $4.906 \AA$ between the adjacent $\mathrm{Mn}$ ions is shorter than that of $5.278 \AA$ found in $\left[\mathrm{Mn}\left({ }^{5 \mathrm{Cl}}\right.\right.$ saltmen $\left.) \mathrm{H}_{2} \mathrm{O}(\mathrm{MeOH})\right]\left\{\left[\mathrm{Mn}\left({ }^{5 \mathrm{Cl}}\right.\right.\right.$ saltmen $)\left(\mathrm{H}_{2} \mathrm{O}\right) \mathrm{Mn}\left({ }^{5 \mathrm{Cl}}\right.$ saltmen $)(\mathrm{MeOH})$ $\left.\left.\mathrm{W}(\mathrm{CN})_{8}\right]\right\}$ [71]. Four of the seven non-bridging cyanide groups of the $\left[\mathrm{W}(\mathrm{CN})_{8}\right]^{3-}$ anion are involved in the intermolecular 3D hydrogen-bonding network, see Figure 2 In the crystal lattice there are seven positions occupied by $\mathrm{H}_{2} \mathrm{O}$ molecules with the total occupancy of 3.75 and one $\mathrm{MeCN}$ molecule, which is not engaged in hydrogen bonding.

The powder XRD data for 2 are presented in Figure S3, SI. The diffractogram of 2 differs from the powder X-ray diffraction (PXRD) simulation of $\mathbf{1}$ and the related chain compound $\left\{[\mathrm{Mn}(5 \mathrm{TMAMsalen})]\left[\mathrm{Fe}(\mathrm{CN})_{6}\right]\right\}_{n}$ [48]. Considering the fact that 2 has the composition of [Mn(5TMAMsalen) W(CN) $\left.)_{8}\right]\left(\mathrm{H}_{2} \mathrm{O}\right)_{8}\left(\mathrm{CH}_{3} \mathrm{CN}\right)$ with a 1:1 ration for $\mathrm{Mn}: \mathrm{W}$, two organizations of a bimetallic product in the solid are possible. One of them is a tetranuclear moiety formed from the two dimers [Mn(5TMAMsalen $)\left(\mathrm{H}_{2} \mathrm{O}\right) \mathrm{W}(\mathrm{CN})_{8}$ ] by removing the aqua ligands coordinated to the Mn-centers. This can result in a new $0 \mathrm{D}$ assembly by means of a mutual bridging of the \{Mn(5TMAMsalen)\} units by phenolate oxygen atoms, similar to that in reference [47], and forming the ${ }_{7}(\mathrm{CN})-\mathrm{W}-\mathrm{CN}-\mathrm{Mn}(-\mathrm{O}-)_{2}-\mathrm{Mn}-\mathrm{NC}-\mathrm{W}(\mathrm{CN})_{7}$ core. However, in such a case the valence stretches of $\mathrm{CN}$ would not experience some significant shifting in higher frequencies, such as what takes place for 2. Another option at the 1:1 metal ratio is a coordination linear polymer comprising of the $-\mathrm{CN}-\mathrm{Mn}-\mathrm{NC}-\mathrm{W}-$ repeating moieties. This molecular structure of the compound is in better agreement with the experimental data.

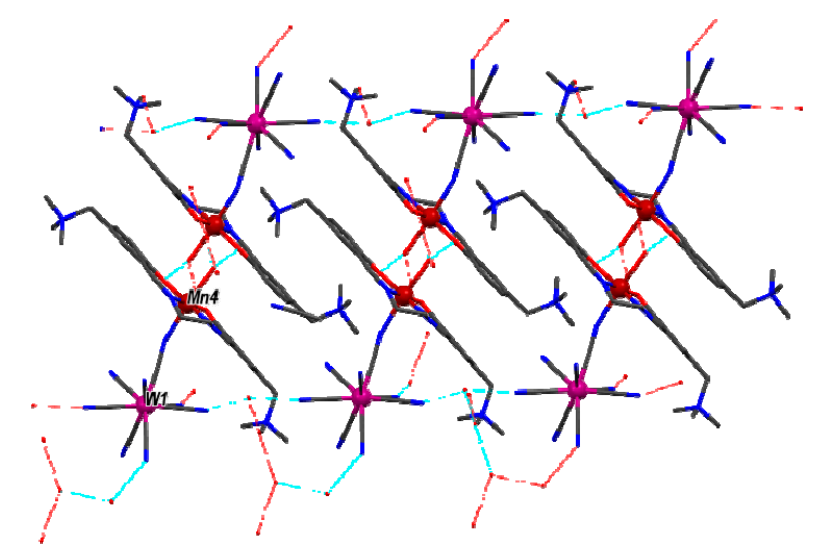

Figure 2. System of hydrogen bonding in 1. Hydrogen atoms are omitted for clarity.

\subsection{Magnetic Properties}

\subsubsection{Magnetic Behavior of 1}

The temperature dependence of the $\chi_{M} T$ product for 1 is presented in Figure 3 . The $\chi_{M} T$ value at $250 \mathrm{~K}$ is $3.30 \mathrm{~cm}^{3} \cdot \mathrm{K} / \mathrm{mol}$, which is very close to $3.34 \mathrm{~cm}^{3} \cdot \mathrm{K} / \mathrm{mol}$ expected for the high temperature limit for the pair of spins $S_{\mathrm{Mn}}=2$ and $S_{\mathrm{W}}=\frac{1}{2}$, and $g=2$. Furthermore, $\chi_{M} T$ decreases monotonically, pointing to an antiferromagnetic interaction between the spins, and reaches about $1.3 \mathrm{~cm}^{3} \cdot \mathrm{K} / \mathrm{mol}$ at $2 \mathrm{~K}$, which is smaller than the $1.87 \mathrm{~cm}^{3} \cdot \mathrm{K} / \mathrm{mol}$ expected for the total spin of $3 / 2$ in the ground state of antiferromagnetically coupled $\mathrm{Mn}^{\mathrm{III}}$ and $\mathrm{W}^{\mathrm{V}}$. This may be associated with the zero-field splitting in the Jahn-Teller distorted $\mathrm{Mn}^{\mathrm{III}}$ complex, and/or antiferromagnetic intermolecular interaction. No sign of magnetic ordering was observed down to $1.8 \mathrm{~K}$, using low field zero-field cooling/field cooling $\mathrm{ZFC} / \mathrm{FC}$ ) and AC susceptibility measurements (See Figures S4 and S5 in SI). 
To simulate the magnetic behavior of 1, we used the model of two spins with a Heisenberg exchange interaction $J$ between them. The zero-field splitting of $\mathrm{Mn}^{\mathrm{III}}$ was taken into account using the axial approximation with the $D$ term only.

$$
\hat{H}=-J S_{M n} S_{W}+D\left[S_{z, M n}^{2}-S_{M n}\left(S_{M n}+1\right)\right]-g \mu_{B}\left(\mathbf{S}_{M n}+\mathbf{S}_{W}\right) \cdot \mathbf{H}
$$

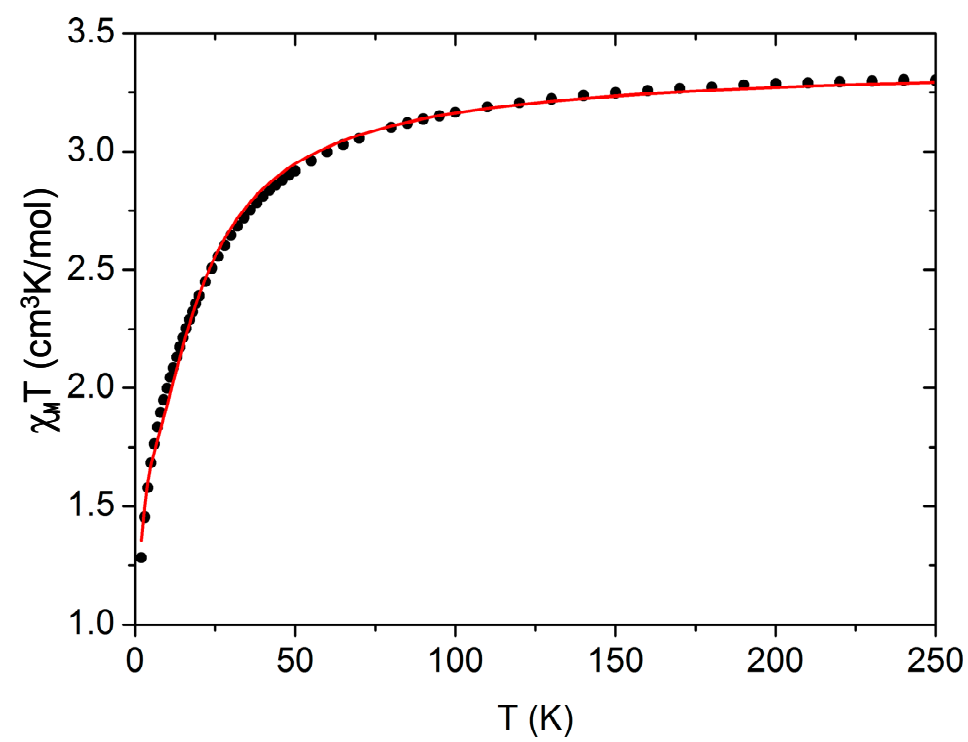

Figure 3. The temperature dependence of the $\chi_{M} \mathrm{~T}$ product for $\mathbf{1}$. The solid line represents the best fit (see text).

The Hamiltonian (1) was diagonalized numerically to calculate the magnetization of the isolated Mn-W pairs $M_{2}(H, T)$. The value averaged over the $\mathbf{H}$ directions was calculated to account for the powder sample. The interdimer interaction was introduced in the mean-field model by numerically solving the equation for the magnetization $M(H, T)=M_{2}(H+\lambda M, T)$, where $\lambda=z J^{\prime} / N_{\mathrm{A}} \mu_{\mathrm{B}}{ }^{2} g^{2}$. The least square fit of the temperature dependence of susceptibility (Figure 3) resulted in the following parameters: $J=-13.1(7) \mathrm{K}, D=-3.0(1.3) \mathrm{K}, z J^{\prime}=-0.16(20) \mathrm{K}$, and the average factor $g=2.00(1)$. The values of $D$ and $z J^{\prime}$ are strongly correlated, which leads to their significant uncertainty.

Based on the values of ZFS for $\mathrm{Mn}^{\mathrm{III}}$ in a similar environment [82], the negative sign of $D$ was assumed for the initial parameters in the fitting procedure. The value of D obtained from the susceptibility fit was used to calculate the $M(H)$ dependencies shown in Figure 4 . At $z J^{\prime}=0$, the obtained parameters were $D=-3.8(2) \mathrm{K}, J=-13.6(2) \mathrm{K}$, and $g=2.00(1)$, with almost the same fit quality judged by the $R^{2}$ value. The values of these fitting parameters are close to those found for a related anionic chain $\left[\mathrm{Zn}\left(\mathrm{HC}\left(3,5-\mathrm{Me}_{2} \mathrm{pz}\right)_{3}\right]_{2}\left[\mathrm{~W}(\mathrm{CN})_{8} \mathrm{Mn}\left({ }^{5 \mathrm{Br}}\right.\right.\right.$ salcy) $]$ [56].

In order to verify the consistency of the mean-field term $z J^{\prime}$ value, it is important to evaluate the strength of spin coupling between two $\mathrm{Mn}^{\mathrm{III}}$ ions involved in two $\left\{\left[\mathrm{Mn}^{\mathrm{III}}(5 \mathrm{TMAMsalen})\left(\mathrm{H}_{2} \mathrm{O}\right)\right]\right\}_{2}$ neighboring units, which is mediated by hydrogen bonds between water ligands and $\pi-\pi$ contacts between aromatic rings of the closest $\left[\mathrm{Mn}^{\mathrm{III}}\left(\mathrm{SB}^{+}\right)\right]^{3+}$ (See Figure S6, SI). For this purpose we have calculated the $J_{\mathrm{Mn}-\mathrm{Mn}}$ exchange parameter in the $\left[\left(\mathrm{MnSB}^{+}\left(\mathrm{H}_{2} \mathrm{O}\right)\right]_{2}\right.$ moiety (Figure S6, SI) in terms of a microscopic model based on the multi-electron superexchange theory described in reference [86]; details of such calculations are reported in [87-89].

The electronic characteristics of a pair of $\mathrm{Mn}^{\mathrm{III}}$ ions were obtained from ligand-field (LF) calculations in combination with the angular-overlap model (AOM) [90]. In these calculations, the AOM parameters $e_{\sigma}(\mathrm{O}, \mathrm{N})=10,000 \mathrm{~cm}^{-1}$ and $e_{\sigma}(\mathrm{O}, \mathrm{N}) / e_{\pi}(\mathrm{O}, \mathrm{N})=0.25$ were employed (at the average metal-ligand distance of $R_{0}(\mathrm{Mn}-\mathrm{O})=2.05 \AA$ ), the radial dependence of the AOM parameters having 
been approximated by $e_{\sigma, \pi}(R)=e_{\sigma, \pi}\left(R_{0}\right)\left(R_{0} / R\right)^{n}$ with $n=4$. LF calculations for $\mathrm{Mn}^{\mathrm{III}}$ ions in the $\left\{\mathrm{MnSB}^{+}\left(\mathrm{H}_{2} \mathrm{O}\right)\right\}$ unit were performed with the $B=600$ and $C=3400 \mathrm{~cm}^{-1}$ Racah parameters and the $\mathrm{Mn} \rightarrow$ Mn charge-transfer energy fixed at $U_{0}(\mathrm{~W} \rightarrow \mathrm{Mn})=65,000 \mathrm{~cm}^{-1}(8 \mathrm{eV})$. The set of one electron matrix elements, $<\mathrm{d}_{i}(\mathrm{~A})|h| \mathrm{d}_{j}(\mathrm{~B})>$, related to the magnetic orbitals $3 \mathrm{~d}_{i}(\mathrm{~A})$ and $3 \mathrm{~d}_{j}(\mathrm{~B})$ (with the orbital indexes $i, j=x y, y z, z x, x^{2}-y^{2}$, and $z^{2}$ ) and centered on the pair of $\mathrm{Mn}^{\mathrm{III}}$ ions, was obtained from extended Hückel calculations based on the atomic parameterization reported in [91], as well as the real geometry of the $\left\{\left(\mathrm{MnSB}^{+}\left(\mathrm{H}_{2} \mathrm{O}\right)\right\}_{2}\right.$ unit (Figure $\mathrm{S6}$, SI) using the projection procedure described in [92].

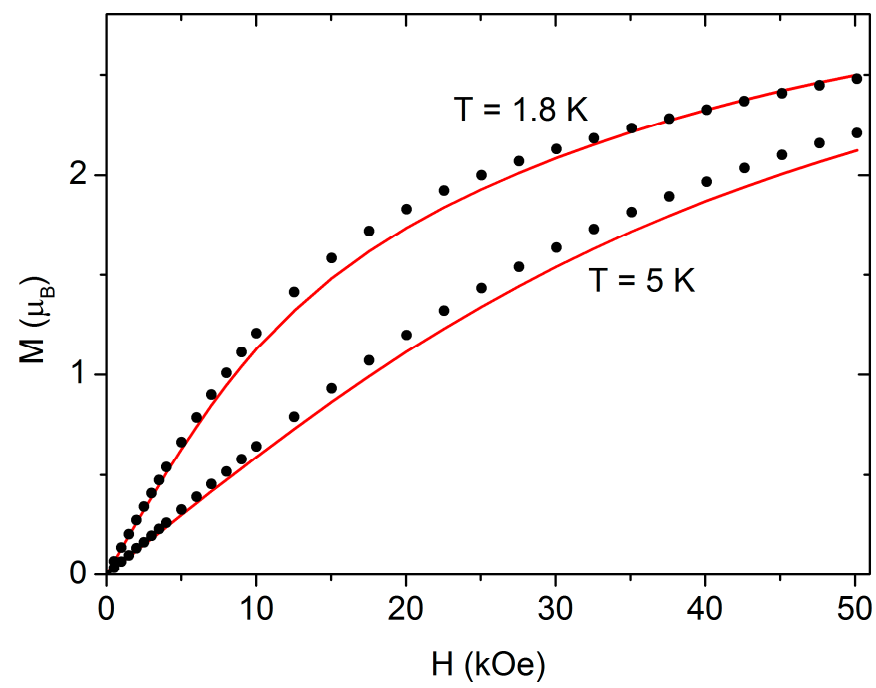

Figure 4. Magnetization of 1 versus the magnetic field measured at 1.8 and $5 \mathrm{~K}$. Solid lines are calculated $\mathrm{M}(\mathrm{H})$ dependencies (see text).

Our calculations have resulted in a small antiferromagnetic exchange parameter $J_{M n-M n}$ of $-0.033 \mathrm{~cm}^{-1}(-0.048 \mathrm{~K})$, which is much smaller than the exchange parameter $J_{\mathrm{Mn}-W}$ of $-13.6 \mathrm{~K}$ within the dimer. This provides evidence that hydrogen bonds along with the $\pi-\pi$ contacts between ligand aromatic rings are poor mediators of spin coupling between $\mathrm{Mn}^{\mathrm{III}}$ ions in the $\left\{\left(\mathrm{MnSB}^{+}\left(\mathrm{H}_{2} \mathrm{O}\right)\right\}_{2}\right.$ unit. This suggests that $\left\{\left[\mathrm{Mn}\left(\mathrm{SB}^{+}\right) \mathrm{H}_{2} \mathrm{O}\right]\left[\mathrm{W}(\mathrm{CN})_{8}\right]\right\}$ molecular clusters are magnetically isolated and do not form 1D magnetic chains in the structure of $\mathbf{1}$. It is also noteworthy that the calculated parameter $J_{M n-M n}$ of $-0.033 \mathrm{~K}$ is reasonably consistent with the value of the molecular field parameter $z J^{\prime}=$ $-0.16(20) \mathrm{K}$ obtained from the fitting calculations. This justifies the approach of using the isolated $\mathrm{W}-\mathrm{Mn}$ dimers in terms of Equation (1).

\subsubsection{Magnetic Behavior of 2}

The cryomagnetic data for $\mathbf{2}$ is noticeably different from that for $\mathbf{1}$. The temperature dependences of the $\chi_{M} T$ product for 2 obtained at magnetic fields of 30 Oe and $5 \mathrm{kOe}$ are presented in Figure 5. Starting from a constant value of $3.3 \mathrm{~cm}^{3} \cdot \mathrm{K} \cdot \mathrm{mol}^{-1}$ at high temperatures, $\chi_{M} T$ values begin to rise, reaching a peak of 10.4 and $10.7 \mathrm{~cm} \cdot \mathrm{K} \cdot \mathrm{mol}^{-1}$ at $15 \mathrm{~K}$ for the data obtained at 5000 and $30 \mathrm{Oe}$, respectively, before dropping sharply at lower temperatures for both. Such a behavior was also observed in $[\mathrm{Mn}(\mathrm{SB})]_{2}\left[\mathrm{Mn}(\mathrm{SB}) \mathrm{W}(\mathrm{CN})_{8}\right][54,56]$ and $\mathrm{K}[\mathrm{Mn}(\text { acacen })]_{2}\left[\mathrm{~W}(\mathrm{CN})_{8}\right] \cdot 2 \mathrm{H}_{2} \mathrm{O}[57]$, and indicates the presence of significant intramolecular $\mathrm{Mn}^{\mathrm{III}}-\mathrm{W}^{\mathrm{V}}$ ferromagnetic interactions through cyanide bridges. A fit of the Seiden model [93] for an alternating chain composed of $\frac{1}{2}$ Heisenberg spins for 2 is described by the Hamiltonian Equation (2)

$$
\hat{H}=-2 J \sum_{i}\left(S_{M n}^{i}+S_{M n}^{i+1}\right) \cdot S_{W}^{i}{ }^{\prime}
$$


to the data obtained at $5 \mathrm{kOe}$ in the temperature range of 50 to $300 \mathrm{~K}$ was performed using a single coupling constant $J$ value, assumed to be identical for all W-Mn pairs, and $g_{W}=2.0$ was fixed. This approximation delivered $g_{M n}=2.11(3)$ and $J=46.1(5.2) \mathrm{K}$, which indicates a strong enough ferromagnetic coupling between the W and Mn centers similar to data of Hong's group [54].

Additionally, to estimate the interactions between the chains, the classic Glauber model $\chi_{\mathrm{M}} T=$ $C_{\text {eff }} \exp \left(\Delta_{\xi} / T\right)$ [28] was modified by including the following equation from the mean field theory [94] that accounts for the interaction between the chains: $\chi=\chi_{\text {chain }}\left(1-z J^{\prime} /\left(2 N_{\mathrm{A}} g^{2} \mu_{\mathrm{B}}{ }^{2}\right) \chi_{\text {chain }}\right)$, where $\chi$ represents the susceptibility of a system with weakly interacting chains, $\chi_{\text {chain }}$ is the susceptibility of isolated chains, and $z J^{\prime}$ is a measure of the interchain interaction. The parameters obtained from the fit of the aforementioned model to the data obtained in $300 \mathrm{Oe}$ in the temperature range of 15 to $50 \mathrm{~K}$ are as follows: the domain wall formation energy $\Delta_{\xi} / k_{\mathrm{B}}=22.5(5) \mathrm{K}, \mathrm{C}_{e f f}=2.91(4) \mathrm{cm}^{3} \cdot \mathrm{K} \cdot \mathrm{mol}^{-1}$, and $z J^{\prime} / k_{\mathrm{B}}=-0.8(2) \mathrm{K}\left(-0.53(9) \mathrm{cm}^{-1}\right.$ ) (assuming an effective $g=2.0$ ), which is within the range for metamagnetic SCMs [95,96].

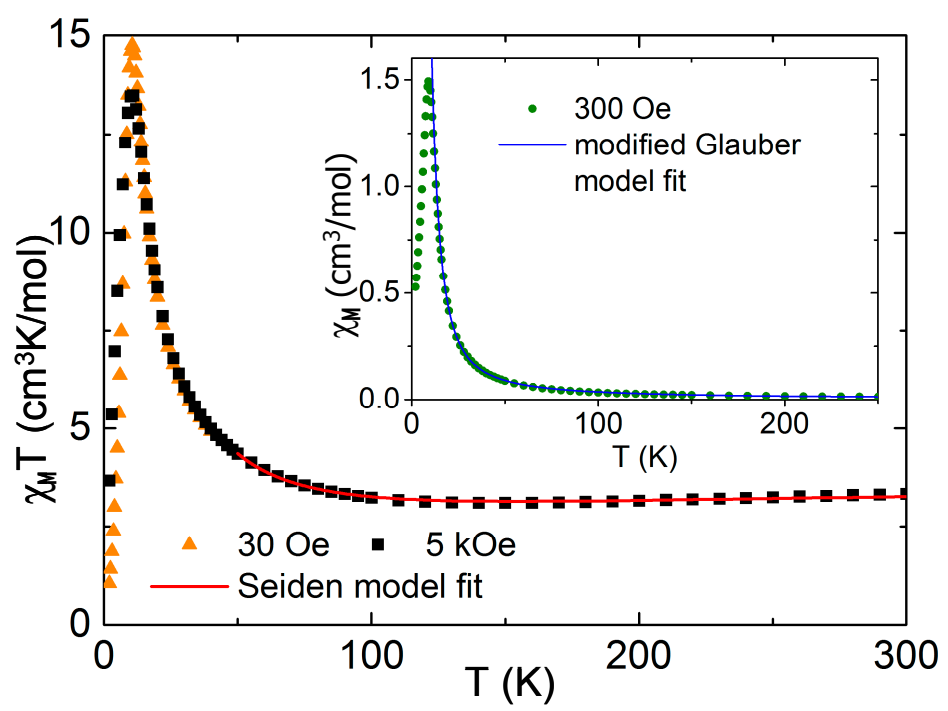

Figure 5. The temperature dependence of the $\chi_{M} \mathrm{~T}$ products for 2 at different fields. The red line represents a Seiden model fit to the $5 \mathrm{kOe}$ data. Inset: $\chi_{M}$ as a function of temperature at 300 Oe with a modified Glauber model fit (see text).

The magnetization vs. field curve of 2 measured at $2 \mathrm{~K}$ (Figure 6) proves that the compound is a metamagnet which undergoes a spin-flip transition at $2 \mathrm{kOe}$. The $\mathrm{M}$ value reached at $50 \mathrm{kOe}$ is equal to $2.7 \mu_{B}$ per $\mathrm{Mn}^{\mathrm{II}}-\mathrm{W}^{\mathrm{V}}$ unit, which is far from the theoretical value of $5.0 \mu_{B}$ expected for a ferromagnetically coupled $\mathrm{Mn}^{\mathrm{III}}$ ion with $S=2$ and $\mathrm{W}^{\mathrm{V}}$ with $S=1 / 2$ and $g_{a v}=2.0$. The estimated saturation magnetic field, $H_{A}$, for 2 is about $91 \mathrm{kOe}$, and is of the same order of the values of 100, 108, and $120 \mathrm{kOe}$ found for SCMs based on neutral [Mn(5TMAMsalen)(Cr/Fe)(CN) 6 [48] and anionic $\left[\mathrm{Mn}^{\mathrm{III}} \text { (acacen)Fe }{ }^{\mathrm{III}}(\mathrm{CN})_{6}\right]^{2-}$ [85] fragments, respectively. It is a consequence of the $\mathrm{Mn}^{\mathrm{III}}$ ion anisotropy. The antiferromagnetic behavior at low fields is further confirmed by the ZFC/FC experiment (Figure S7, SI), from which the Néel temperature of $9.5 \mathrm{~K}$ is clearly visible. Our previous analysis of the thermal dependence of the $\chi T$ product explains this metamagnetic behavior, which is derived from weak antiferromagnetic interactions between ferromagnetically coupled chains.

The AC susceptibility of 2 reveals a frequency dependence below 4 K (Figures S8-S11, SI). Considering the metamagnetic character of this compound, measurements of AC susceptibility versus the applied DC field were performed at four different temperatures (Figure S10, SI). They show significant maxima for $H_{D C}=2 \mathrm{kOe}$ which concurs with the value of the spin-flip field. As slow magnetic relaxations in such systems can be enhanced by applying sufficient DC fields [30], AC measurements were conducted with the DC field of $2 \mathrm{kOe}$ applied as well. In these conditions, the 
frequency dependence became more visible, which is shown in Figures S9 and S11 (SI). The Mydosh parameter, defined as the temperature shift of the $\chi^{\prime}$ peak on a decade of frequency $\Delta T_{m} /\left[T_{m} \Delta \log (v)\right]$ equals 0.13 , which is above the range typical for spin-glasses [97].

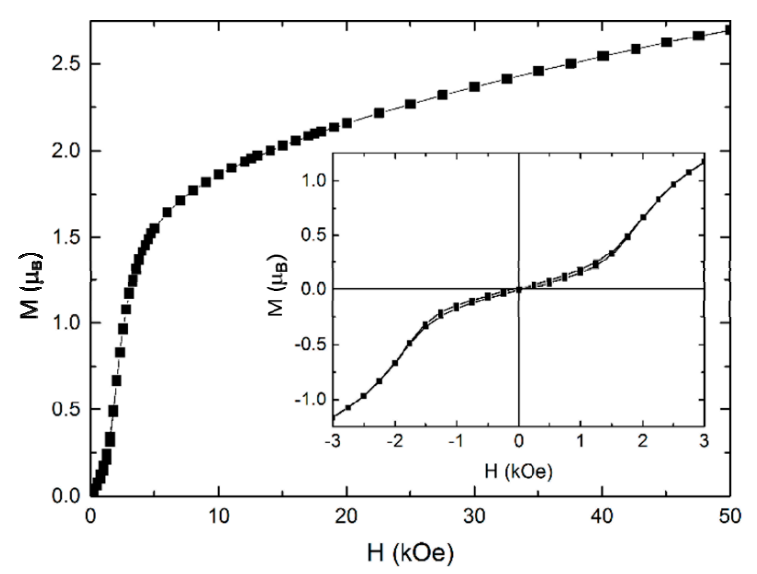

Figure 6. The magnetization of 2 versus the field at $T=2 \mathrm{~K}$. Inset: magnified low-field region. The solid lines guide the eye.

Due to the DC field dependence, frequency plots of the AC susceptibility for 2 were measured at $H_{D C}=0$ and $2 \mathrm{kOe}$ over a series of temperatures (Figure S11, SI). The generalized Debye model [98] was fitted to $\chi^{\prime}$ and $\chi^{\prime \prime}$ simultaneously for each temperature. The fitted parameters were $\chi$ in the limits $\chi_{0}$ and $\chi_{\infty}$, the relaxation time $\tau$, and the parameter $\alpha$ describing the distribution of $\tau$. The fits for 2 delivered the $\alpha$ values in the range from $0.12-0.38$ and thus confirmed the SCM character of the assembly. The parameters $\tau$ and $\alpha$ are listed in Table S1, SI.

Plots of $\ln \tau$ vs. $T^{-1}$ derived from the generalized Debye model fits to the data in the 0 and $2 \mathrm{kOe}$ DC fields are presented in Figure 7. The values found from the linear fits of the Arrhenius law $\ln \tau=$ $\ln \tau_{0}+\Delta_{\tau} / k_{\mathrm{B}} T$ of $\tau_{0}$ were similar and equal to 32(15) and 36(15) ps for 0 and $2 \mathrm{kOe}$, respectively, well within the typical range for SCMs [11,12]. The respective $\Delta_{\tau} / k_{B}$ values were $48.4(1.2)$ and $44.9(1.0) \mathrm{K}$. Application of the DC field results in a slight lowering of the energy barrier, which has been observed for other metamagnetic SCMs [95]. The calculated value of the activation energy $\Delta_{A}=\Delta_{\tau}-2 \Delta_{\xi}$ is close to zero.

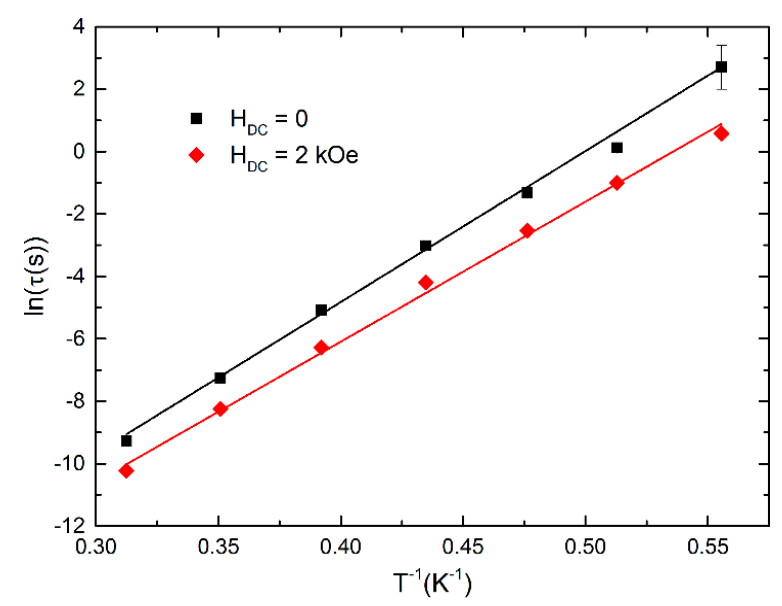

Figure 7. Arrhenius plots of $\ln \tau$ versus $T^{-1}$ for 2 derived from the generalized Debye model, fit to the data in the 0 and $2 \mathrm{kOe}$ DC fields. Solid lines represent linear fits. 


\section{Experimental Section}

All chemical reagents and solvents were purchased from Alfa or Sigma-Aldrich and were used without further purification. [Mn(5-TMAMsalen $\left.)\left(\mathrm{H}_{2} \mathrm{O}\right)_{2}\right]\left(\mathrm{ClO}_{4}\right)_{3} \cdot \mathrm{H}_{2} \mathrm{O}$ [99] and $\mathrm{K}_{3}\left[\mathrm{~W}(\mathrm{CN})_{8}\right]\left(\mathrm{H}_{2} \mathrm{O}\right)_{2}[100,101]$ were prepared using published procedures. Elemental $(\mathrm{C}, \mathrm{H}, \mathrm{N})$ analyses were carried out by standard methods with a Euro-Vector 3000 analyzer (Eurovector, Redavalle, Italy). FTIR spectra were measured with a NICOLET spectrophotometer (Thermo Electron Scientific Instruments LLC, Madison, WI, USA) in the $4000-375 \mathrm{~cm}^{-1}$ range. Thermogravimetric measurements were performed by means of a 50 Thermobalance TG 209 F1 Iris®NETZSCH (NETZSCH-Gerätebau $\mathrm{GmbH}$, Selb, Germany) in $\mathrm{He}(70 \mathrm{~mL} / \mathrm{min}), \mathrm{Al}_{2} \mathrm{O}_{3}$ crucible, sample weight of about $5 \mathrm{mg}$, heating rate of $10.0 \mathrm{~K} / \mathrm{min}$, and temperature range from $25-350{ }^{\circ} \mathrm{C}$. The experimental results were treated using standard software [102]. Powder X-ray measurements were performed using $\mathrm{Cu}-\mathrm{K} \alpha$ radiation $\left(\lambda=1.5418 \AA\right.$ ) with an $X^{\prime}$ Pro powder diffractometer (PANalytical Inc., Almelo, Netherlands) at room temperature.

\subsection{Single-Crystal X-Ray Diffraction}

SCXRD studies of $\mathbf{1}$ were carried out by means of an Xcalibur Ruby Gemini diffractometer (Agilent Technologies inc., Oxford, UK) at $293 \mathrm{~K}$ using graphite-monochromated Mo-K $\alpha$ radiation $(\lambda=0.71073 \AA)$. The intensity data were integrated using the related analysis software [103]. An absorption correction based on the crystal faces was applied to the data sets (analytical) [104]. The structure of 1 was solved by direct methods using the $\mathrm{SIR}^{97}$ program [105] combined with Fourier difference syntheses and refined against $F$ using reflections with $[I / \sigma(I)>3]$ by means of the CRYSTALS software program [106] with the Robust Weighting method based on the Chebychev polynomial: $w=P\left[1-\left(\operatorname{deltaF} / 6^{*} \text { sigmaF }\right)^{2}\right]^{2}$, where $\left.P=1.0 /\left[A_{0} T_{0}(x)+A_{1} T_{1}(x) \ldots+A_{n-1}\right]^{*} T_{n-1}(x)\right], A_{i}$ are the Chebychev coefficients (19.4 15.010 .715 .3$)$, and $x=F_{\text {calc }} / F_{\text {max }}[107,108]$. All atomic displacement parameters for non-hydrogen atoms were refined with anisotropic terms. The hydrogen atoms were theoretically located based on the conformation of the supporting atom and refined by using the riding model. Selected crystallographic data are presented in Table 3.

Table 3. Crystallographic data and structure refinement summary for $\mathbf{1}$.

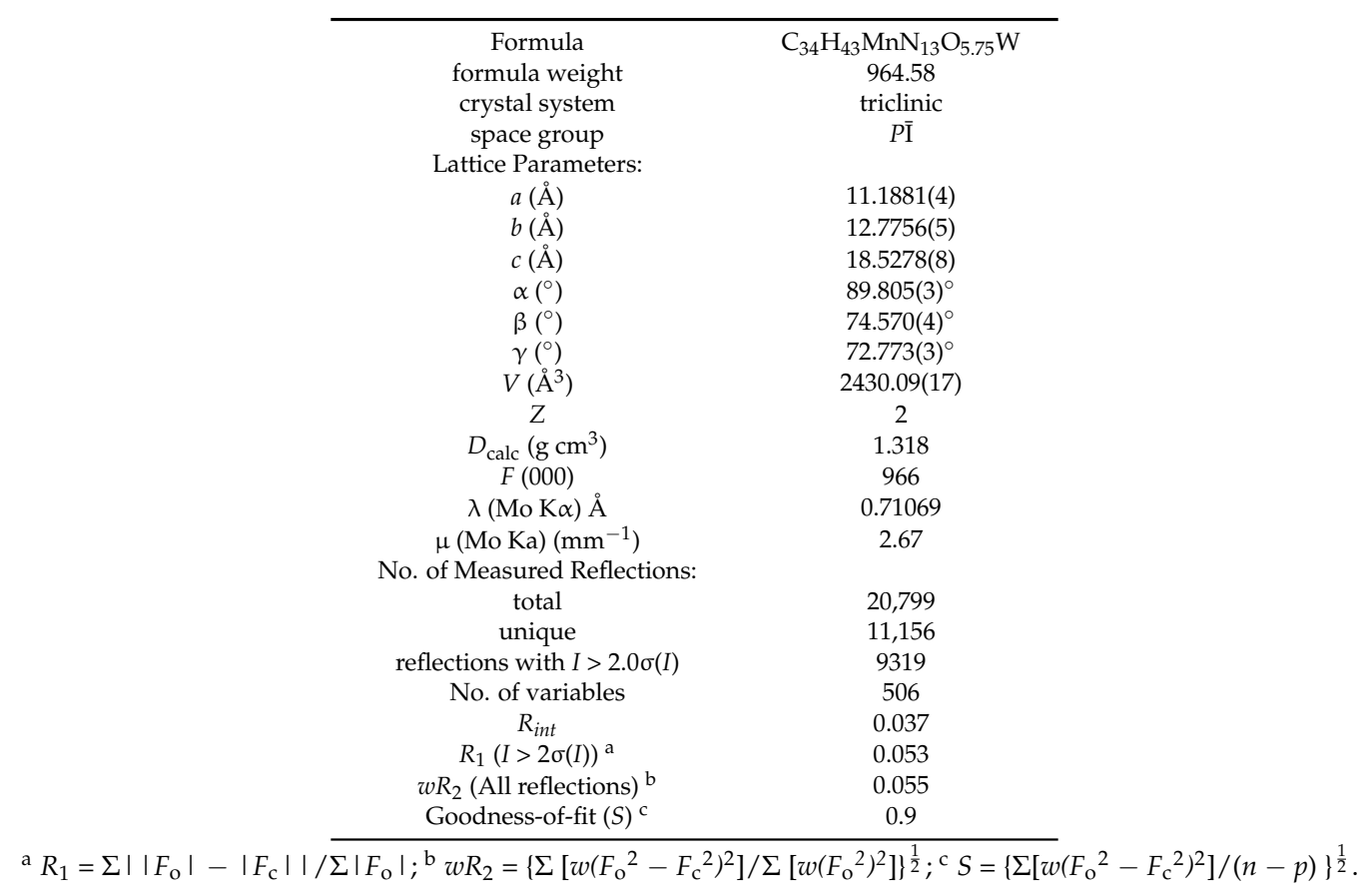




\subsection{Magnetic Measurements}

All measurements of magnetic properties were performed using a Quantum Design MPMS 5XL SQUID magnetometer (Quantum Design, Inc., San Diego, CA, USA) in the range of temperature from $1.8-300 \mathrm{~K}$ and a magnetic field up to $50 \mathrm{kOe}$.

\subsection{Synthetic Details}

\subsubsection{Synthesis of Complex 1, [Mn(5TMAMsalen) $\left.\left(\mathrm{H}_{2} \mathrm{O}\right)\right]\left[\mathrm{W}(\mathrm{CN})_{8}\right]\left(\mathrm{H}_{2} \mathrm{O}\right)_{4.75}\left(\mathrm{CH}_{3} \mathrm{CN}\right)$}

The complex was obtained by layering of the constituents' solutions. A solution of $\mathrm{K}_{3}\left[\mathrm{~W}(\mathrm{CN})_{8}\right]\left(\mathrm{H}_{2} \mathrm{O}\right)_{2}(25 \mathrm{mg}, 0.05 \mathrm{mmol})$ in water $(8 \mathrm{~mL})$ was divided into four portions, which were placed in narrow (diameter $5 \mathrm{~mm}$ ) glass tubes. Aliquots $(2 \mathrm{~mL})$ of a 1:3 mixture of water/acetonitrile were layered on top of the portions of the $\mathrm{K}_{3}\left[\mathrm{~W}(\mathrm{CN})_{8}\right]\left(\mathrm{H}_{2} \mathrm{O}\right)_{2}$ solution as a dividing buffer layer. This provided a slow diffusion from a third, top layer, consisting of a $2 \mathrm{~mL}$ aliquot of a solution of [Mn(5TMAMsalen $\left.)\left(\mathrm{H}_{2} \mathrm{O}\right)_{2}\right]\left(\mathrm{ClO}_{4}\right)_{3}\left(\mathrm{H}_{2} \mathrm{O}\right)(41 \mathrm{mg}, 0.05 \mathrm{mmol})$ in acetonitrile $(8 \mathrm{~mL})$. These glass tubes were capped by parafilm and left undisturbed for three weeks in the dark until the elongated block-shaped brown-green crystals of $\mathbf{1}$ had formed. Yield: $86.5 \% . \mathrm{C}_{34} \mathrm{H}_{43} \mathrm{MnN}_{13} \mathrm{O}_{5.75} \mathrm{~W}$ (964.57) calcd. C 42.34, H 4.49, N 18.88; found C 42.54, H 4.53, N 19.00. IR: v = 3417.6, 3035.4, 1978.6, 1615.4, 1544.2, 1470.5, 1438.5, 1384.4, 1328.4, 1298.0, 1257.0, 1235.4, 1173.1, 1148.3, 1092.6, 1049.1, 977.1, 919.4, 880.1, $851.8,832.9,818.8,795.9,759.9,738.2,674.0,636.0,603.3,570.3,496.8,465.5 \mathrm{~cm}^{-1}$.

\subsubsection{Synthesis of Complex 2, $\left[\mathrm{Mn}(5 \mathrm{TMAMsalen}) \mathrm{W}(\mathrm{CN})_{8}\right]\left(\mathrm{H}_{2} \mathrm{O}\right)_{8}\left(\mathrm{CH}_{3} \mathrm{CN}\right)$}

To a stirred light yellow solution of $\mathrm{K}_{3}\left[\mathrm{~W}(\mathrm{CN})_{8}\right]\left(\mathrm{H}_{2} \mathrm{O}\right)_{2}(25 \mathrm{mg}, 0.05 \mathrm{mmol})$ in $\mathrm{H}_{2} \mathrm{O}(2.5 \mathrm{~mL})$, a dark brown solution of [Mn(5TMAMsalen) $\left.\left(\mathrm{H}_{2} \mathrm{O}\right)_{2}\right]\left(\mathrm{ClO}_{4}\right)_{3}\left(\mathrm{H}_{2} \mathrm{O}\right)(41 \mathrm{mg}, 0.05 \mathrm{mmol})$ in acetonitrile $(2.5 \mathrm{~mL})$ was added dropwise. The precipitated product was stirred for a few minutes at $70{ }^{\circ} \mathrm{C}$, and then collected by filtration. The solid was washed twice with $\mathrm{H}_{2} \mathrm{O}(2 \mathrm{~mL})$, twice with $\mathrm{MeCN}(2 \mathrm{~mL})$, and once with $\mathrm{Et}_{2} \mathrm{O}(2 \mathrm{~mL})$ and was then air-dried. Yield: 97\%. IR (KBr): $v=3306,2956,2870,2380$, $1645,1449,1115,535,475 \mathrm{~cm}^{-1} . \mathrm{C}_{34} \mathrm{H}_{51} \mathrm{MnN}_{13} \mathrm{O}_{10} \mathrm{~W}(1040.63)$ calcd. C 39.24, H 4.94, N 17.49; found C 39.25, H 4.92, N 17.52. IR: $v=3443.8,3039.5,1980.5,1614.6,1544.2,1470.4,1415.1,1386.2,1334.2,1293.1$, 1257.0, 1235.2, 1203.3, 1172.9, 1147.7, 1092.3, 1051.0, 998.9, 974.7, 918.0, 878.0, 850.2, 830.7, 818.7, 796.5, $762.9,736.4,678.5,637.0,604.6,572.2,497.4,467.0 \mathrm{~cm}^{-1}$.

Compound 2 was also obtained from 1: finely ground $1(35 \mathrm{mg}, 0.036 \mathrm{mmol})$ was dissolved in hot acetonitrile $(7 \mathrm{~mL})$. To this solution, distilled water $(2 \mathrm{~mL})$ was added. A brown powder was formed after $5 \mathrm{~min}$ of continuous stirring. The precipitate was separated by centrifugation, washed twice with $\mathrm{H}_{2} \mathrm{O}(2 \mathrm{~mL})$, once with $\mathrm{MeCN}(2 \mathrm{~mL})$, and once with $\mathrm{Et}_{2} \mathrm{O}(2 \mathrm{~mL})$ and was then dried under vacuum. Yield: $89 \%$. According to elemental analysis, the sample obtained from 1 contains less solvate water molecules compared to that prepared from the non-dimerized constituents. $\mathrm{C}_{34} \mathrm{H}_{45} \mathrm{MnN}_{13} \mathrm{O}_{6} \mathrm{~W}$ (970.58) calcd. C 42.07, H 4.67, N 18.76; found C 42.10, H 4.72, N 18.67.

\section{Conclusions}

Apparently, both studied complexes have a different organization in the solid state, as was evident from their diffractograms (Figure S3, SI). If for 1, the molecular structure was determined from the SCXRD data, then a lack of the single crystal structure for $\mathbf{2}$ does not permit us to definitely explain why the magnetic behavior of this compound is so different compared to 1 . However, our conclusion is that 2 is a 1D coordination chain, and is based on the totality of the experimental facts. First, compound 2, having a ratio $\left[\mathrm{Mn}\left(\mathrm{SB}^{+}\right)\right]^{3+} /\left[\mathrm{W}(\mathrm{CN})_{8}\right]^{3-}=1: 1$, is insoluble in any solvent and can be obtained from $\mathbf{1}$ (See experimental section). These three features, taken together, support a polymeric character of $\mathbf{2}$. Second, the majority of the $v_{\mathrm{CN}}$ peaks in the IR spectrum of $\mathbf{2}$ (Table 1) are slightly shifted towards higher frequencies compared to those of $\mathbf{1}$. Furthermore, compound $\mathbf{2}$ is somewhat more thermally stable than compound $\mathbf{1}$. Two previous statements are also consistent with a more linked character of 
the $\left[\mathrm{W}(\mathrm{CN})_{8}\right]^{3-}$ metalloligand in the solid state. Third, the magnetic properties of compound 2, both static and dynamic, do not contradict the proposed structure.

An intriguing difference in the character of the spin coupling between the magnetic centers in $\mathbf{1}$ and $\mathbf{2}$ is certainly caused by a dissimilarity of their molecular structures in general and particularly by the geometry of the dimeric $\mathrm{W}-\mathrm{CN}-\mathrm{Mn}$ unit. To clarify this situation, we continue the challenge of single crystal growth to elucidate the structure of 2 .

In summary, the two low dimensional assemblies constructed from the $\left[\mathrm{W}(\mathrm{CN})_{8}\right]^{3-}$ metalloligand and the anisotropic $\mathrm{Mn}^{\mathrm{III}}$ Schiff base complex have been prepared and characterized. These two compounds are the first examples of the neutral species among the small family of heterobimetallic compounds involving octacyanotungstate $(\mathrm{V})$.

Supplementary Materials: The following are available online at www.mdpi.com/2312-7481/3/2/16/s1, Figure S1: TG data for 1 and 2; Figure S2: DTG data for 1 and 2; Figure S3: (a) diffractograms for 1: experimental (red), simulated (black); simulated for 1 and 2; Figure S4: Zero field-cooling/field cooling $\chi$ vs. $T$ for $1(\mathrm{H}=20 \mathrm{Oe})$; Figure S5: AC susceptibility versus temperature for $1 . H_{\mathrm{AC}}=3 \mathrm{Oe}, f_{\mathrm{AC}}=10 \mathrm{~Hz}$; Figure S6: The molecular structure of $\left[\left(\mathrm{MnSB}^{+}\left(\mathrm{H}_{2} \mathrm{O}\right)\right]_{2}\right.$ dimer in compound I. The $\mathrm{O} \ldots$ H hydrogen bonds mediating spin coupling between two $\mathrm{Mn}^{\mathrm{III}}$ ions; Figure S7: Zero-field cooling and field cooling magnetic susceptibility versus temperature for 2 measured in a DC field of 15 Oe; Figure S8: AC susceptibility versus temperature for 2 measured in $H_{\mathrm{DC}}=0$ Oe and $H_{\mathrm{AC}}=3$ Oe at $f=10 \mathrm{~Hz}$; Figure S9: AC susceptibility of 2 as a function of temperature measured over a series of AC frequencies in (a) zero DC field and (b) DC field of 2 kOe, Figure S10: AC susceptibility of 2 as a function of $H_{\mathrm{DC}}$ at four temperatures; (a) $\chi^{\prime},(\mathrm{b}) \chi^{\prime \prime} . f_{\mathrm{AC}}=10 \mathrm{~Hz}, H_{\mathrm{AC}}=3$ Oe, Figure S11: AC susceptibility of 2 measured as a function of AC frequency over a range of temperatures in (a) 0 and (b) 2 kOe DC field; Table S1: Parameters $\tau$ and $\alpha$ obtained from the generalized Debye model fits to the AC data vs. frequency for sets measured in 0 and 2 kOe DC field.

Acknowledgments: This work was supported by the Russian Foundation for Basic Research under grant number 16-03-00880-a We are grateful to Michał Rams for his help in collection and analysis of the magnetic measurements data.

Author Contributions: Kira E. Vostrikova conceived, designed, and performed the chemical experiment, as well as wrote the paper; Guillaume Pilet performed a crystallographic study and participated in the article editing. Anna M. Majcher collected and fitted the majority of the magnetic data, and Vladimir S. Mironov contributed to the theoretical estimation of the interdimer magnetic interaction for compound $\mathbf{1}$.

Conflicts of Interest: The authors declare no conflict of interest.

\section{References}

1. Gatteschi, D.; Sessoli, R.; Villain, J. Molecular Nanomagnets; Oxford University Press: Oxford, UK, 2006; pp. $1-408$.

2. Coulon, C.; Miyasaka, H.; Clérac, R. Single-Chain Magnets: Theoretical Approach and Experimental Systemsin. In Structure and Bonding; Winpenny, R., Ed.; Springer: Berlin/Heidelberg, Germany, 2006; pp. 163-206.

3. Bogani, L.; Wernsdorfer, W. Molecular spintronics using single-molecule magnets. Nat. Mater. 2008, 7 , 179-186. [CrossRef]

4. Juan, B.; Fernando, L.; Fernández, J.F. (Eds.) Molecular Magnets: Physics and Applications. In NanoScience and Technology; Springer: Berlin/Heidelberg, Germany, 2014; pp. 1-395.

5. Lescouëzec, R.; Toma, L.; Vaissermann, J.; Verdaguer, M.; Delgado, F.S.; Ruiz-Pérez, C.; Lloret, F.; Julve, M. Design of single chain magnets through cyanide-bearing six-coordinate complexes. Coord. Chem. Rev. 2005, 249, 2691-2729. [CrossRef]

6. Miyasaka, H.; Clerac, R. Synthetic Strategy for Rational Design of Single-Chain Magnets. Bull. Chem. Soc. Jpn. 2005, 78, 1725-1748. [CrossRef]

7. Miyasaka, H.; Julve, M.; Yamashita, M.; Clérac, R. Slow Dynamics of the Magnetization in One-Dimensional Coordination Polymers: Single-Chain Magnets. Inorg. Chem. 2009, 48, 3420-3437. [CrossRef] [PubMed]

8. Sun, H.-L.; Wang, Z.-M.; Gao, S. Strategies towards single-chain magnets. Coord. Chem. Rev. 2010, 254, 1081-1100. [CrossRef]

9. Wang, S.; Ding, X.-H.; Li, Y.-H.; Huang, W. Dicyanometalate chemistry: A type of versatile building block for the construction of cyanide-bridged molecular architectures. Coord. Chem. Rev. 2012, 256, 439-464. [CrossRef] 
10. Kang, L.-C.; Zuo, J.-L. Multifunctional Molecular Materials; Ouahab, L., Ed.; Pan Stanford Publishing: Singapore, 2013; pp. 105-131.

11. Zhang, W.-X.; Breedlove, B.; Ishikawa, R.; Yamashita, M. Single-chain magnets: Beyond the Glauber model. RSC Adv. 2013, 3, 3772-3798. [CrossRef]

12. Gatteschi, D.; Vindigni, A. Single-Chain Magnets. In Molecular Magnets; Springer: Berlin/Heidelberg, Germany, 2014; pp. 191-220.

13. Ishikawa, R.; Katoh, K.; Breedlove, B.K.; Yamashita, M. Mn ${ }^{\mathrm{III}}$ (tetrabiphenylporphyrin)-TCNE Single-Chain Magnet via Suppression of the Interchain Interactions. Inorg. Chem. 2012, 51, 9123-9131. [CrossRef] [PubMed]

14. Bhargavi, G.; Rajasekharan, M.V.; Costes, J.-P.; Tuchagues, J.-P. A new end-on azido bridged MnIII single-chain magnet and its dimeric single molecule magnet polymorph. Synthesis, structure and magnetic properties of $\left[\mathrm{Mn}(5-\mathrm{Clsalpn}) \mathrm{N}_{3}\right]_{\mathrm{n}}$ and phenoxo bridged $\left[\mathrm{Mn}(5-\mathrm{Clsalpn}) \mathrm{N}_{3}\right]_{2}$. Dalton Trans. 2013, 42, 8113-8123. [CrossRef] [PubMed]

15. Senapati, T.; Pichon, C.; Ababei, R.; Mathoniere, C.; Clérac, R. Cyanido-Bridged Fe(III)-Mn(III) Heterobimetallic Materials Built From Mn(III) Schiff Base Complexes and Di- or Tri-Cyanido Fe(III) Precursors. Inorg. Chem. 2012, 51, 3796-3812. [CrossRef] [PubMed]

16. Boeckmann, J.; Wriedt, M.; Näther, C. Metamagnetism and Single-Chain Magnetic Behavior in a Homospin One-Dimensional Iron(II) Coordination Polymer. Chem. Eur. J. 2012, 18, 5284-5289. [CrossRef] [PubMed]

17. Zhang, W.-X.; Shiga, T.; Miyasaka, H.; Yamashita, M. New Approach for Designing Single-Chain Magnets: Organization of Chains via Hydrogen Bonding between Nucleobases. J. Am. Chem. Soc. 2012, 134, 6908-6911. [CrossRef] [PubMed]

18. Sahoo, S.; Sutter, J.-P.; Ramasesha, S. Study of Low Temperature Magnetic Properties of a Single Chain Magnet with Alternate Isotropic and Non-collinear Anisotropic Units. J. Stat. Phys. 2012, 147, 181-193. [CrossRef]

19. Liu, R.N.; Hu, P.; Li, L.C.; Liao, D.Z.; Sutter, J.-P. One-dimensional lanthanide complexes bridged by nitronyl nitroxide radical ligands with non-chelating nitrogen donors: Structure and magnetic characterization. Sci. China Chem. 2012, 55, 997-1003. [CrossRef]

20. Li, Z.-X.; Jie, W.; Zha, G.; Wang, T.; Xu, Y. Nitrate-Templated 1D EE-Azide-Cobalt Chain Exhibits Canted Antiferromagnetism and Slow Magnetic Relaxation. Eur. J. Inorg. Chem. 2012, 22, 3537-3540. [CrossRef]

21. Liu, R.; Xiong, C.; Zhao, S.; Wu, J.; Li, Q.; Fang, D. Ruthenium (II) complexes binding to human serum albumin and inducing apoptosis of tumor cells. Inorg. Chem. Commun. 2012, 22, 104-107. [CrossRef]

22. Tomkowicz, Z.; Rams, M.; Balanda, M.; Foro, S.; Nojiri, H.; Krupskaya, Y.; Kataev, V.; Buchner, B.; Nayak, S.K.; Yakhmi, J.V.; et al. Slow Magnetic Relaxations in Manganese(III) Tetra(meta-fluorophenyl)porphyrin-tetracyanoethenide. Comparison with the Relative Single Chain Magnet ortho Compound. Inorg. Chem. 2012, 51, 9983-9994. [CrossRef] [PubMed]

23. Hoshino, N.; Iijima, F.; Newton, G.N.; Yoshida, N.; Shiga, T.; Nojiri, H.; Nakao, A.; Kumai, R.; Murakami, Y.; Oshio, H. Three-way switching in a cyanide-bridged [CoFe] chain. Nat. Chem. 2012, 4, 921-926. [CrossRef] [PubMed]

24. Visinescu, D.; Jeon, I.-R.; Madalan, A.M.; Alexandru, M.-G.; Jurca, B.; Mathoniere, C.; Clérac, R.; Andruh, M. Self-assembly of $\left[\mathrm{Cu}^{\mathrm{II}} \mathrm{Tb}^{\mathrm{III}}\right]^{3+}$ and $\left[\mathrm{W}(\mathrm{CN})_{8}\right]^{3-}$ tectons: A case study of a mixture containing two complexes showing slow-relaxation of the magnetization. Dalton Trans. 2012, 41, 13578-13581. [CrossRef] [PubMed]

25. Yao, M.-X.; Zheng, Q.; Qian, K.; Song, Y.; Gao, S.; Zuo, J.-L. Controlled Synthesis of Heterotrimetallic Single-Chain Magnets from Anisotropic High-Spin 3d-4f Nodes and Paramagnetic Spacers. Chem. Eur. J. 2013, 19, 294-303. [CrossRef] [PubMed]

26. Mougel, V.; Chatelain, L.; Hermle, J.; Caciuffo, R.; Colineau, E.; Tuna, F.; Magnani, N.; Degeyer, A.; Pécaut, J.; Mazzanti, M. A Uranium-Based $\mathrm{UO}^{2+}-\mathrm{Mn}^{2+}$ Single-Chain Magnet Assembled trough Cation-Cation Interaction. Angew. Chem. Int. 2014, 53, 819-823. [CrossRef] [PubMed]

27. Vaz, M.G.F.; Cassaro, R.A.A.; Akpinar, H.; Schlueter, J.A.; Lahti, P.M.; Novak, M.A. A Cobalt Pyrenylnitronylnitroxide Single-Chain Magnet with High Coercivity and Record Blocking Temperature. Chem. Eur. J. 2014, 20, 5460-5467. [CrossRef] [PubMed]

28. Glauber, R.J. Time-Dependent Statistics of the Ising Model. J. Math. Phys. 1963, 4, 294-307. [CrossRef]

29. Suzuki, M.; Kubo, R. Dynamics of the Ising Model near the Critical Point. J. Phys. Soc. Jpn. 1968, 24, 51-60. [CrossRef] 
30. Coulon, C.; Clérac, R.; Lecren, L.; Wernsdorfer, W.; Miyasaka, H. Glauber dynamics in a single-chain magnet: From theory to real systems. Phys. Rev. B 2004, 69, 132408. [CrossRef]

31. Miyasaka, H.; Saitoh, A.; Abec, S. Magnetic assemblies based on Mn(III) salen analogues. Coord. Chem. Rev. 2007, 251, 2622-2664. [CrossRef]

32. Wang, X.-Y.; Avendaño, C.; Dunbar, K.R. Molecular magnetic materials based on 4d and 5d transition metals. Chem. Soc. Rev. 2011, 40, 3213-3238. [CrossRef] [PubMed]

33. Dreiser, J.; Pedersen, K.S.; Schnegg, A.; Holldack, K.; Nehrkorn, J.; Sigrist, M.; Tregenna-Piggott, P.; Mutka, H.; Weihe, H.; Mironov, V.S.; et al. Three-Axis Anisotropic Exchange Coupling in the Single-Molecule Magnets $\left.\mathrm{NEt}_{4}\left[\mathrm{Mn}_{2}^{\mathrm{III}} \text { (5-Brsalen }\right)_{2}(\mathrm{MeOH})_{2} \mathrm{M}^{\mathrm{III}}(\mathrm{CN})_{6}\right](\mathrm{M}=\mathrm{Ru}, \mathrm{Os})$. Chem. Eur. J. 2013, 19, 3693-3701. [CrossRef] [PubMed]

34. Qian, K.; Huang, X.-C.; Zhou, C.; You, X.-Z.; Wang, X.-Y.; Dunbar, K.R. A Single-Molecule Magnet Based on Heptacyanomolybdate with the Highest Energy Barrier for a Cyanide Compound. J. Am. Chem. Soc. 2013, 135, 13302-13305. [CrossRef] [PubMed]

35. Miyasaka, H.; Saitoh, A.; Yamashita, M.; Clérac, R. A Mn ${ }_{2}{ }_{2} \mathrm{Ni}^{\mathrm{II}}$ single-chain magnet separated by a thick isolating network of $\mathrm{BPh}_{4}{ }^{-}$anions. Dalton Trans. 2008, 2422-2427. [CrossRef]

36. Choi, H.J.; Sokol, J.J.; Long, J.R. Raising the Spin-Reversal Barrier in Cyano-Bridged Single-Molecule Magnets: Linear $\mathrm{Mn}_{2}^{\mathrm{III}}{ }_{2} \mathrm{M}^{\mathrm{III}}(\mathrm{CN})_{6}\left(\mathrm{M}=\mathrm{Cr}\right.$, Fe) Species Incorporating [(5-Brsalen)Mn] ${ }^{+}$Units. Inorg. Chem. 2004, 43, 1606-1608. [CrossRef] [PubMed]

37. Miyasaka, H.H.; Takahashi, M.T.; Sugiura, K.; Clérac, R.; Nojiri, H. Cyano-Bridged $\mathrm{Mn}_{3}^{\mathrm{III}} \mathrm{M}^{\mathrm{III}}\left(\mathrm{M}^{\mathrm{III}}=\mathrm{Fe}\right.$, Cr) Complexes: Synthesis, Structure, and Magnetic Properties. Inorg. Chem. 2005, 44, 5969-5971. [CrossRef] [PubMed]

38. Tregenna-Piggott, P.L.W.; Sheptyakov, D.; Keller, L.; Klokishner, S.I.; Ostrovsky, S.M.; Palii, A.V.; Reu, O.S.; Bendix, J.; Brock-Nannestad, T.; Pedersen, K.; et al. Single-Ion Anisotropy and Exchange Interactions in the Cyano-Bridged Trimers $\mathrm{Mn}_{2}{ }_{2} \mathrm{M}^{\mathrm{III}}(\mathrm{CN})_{6}\left(\mathrm{M}^{\mathrm{III}}=\mathrm{Co}, \mathrm{Cr}, \mathrm{Fe}\right)$ Species Incorporating [Mn(5-Brsalen)] $]^{+}$Units: An Inelastic Neutron Scattering and Magnetic Susceptibility Study. Inorg. Chem. 2009, 48, 128-134. [CrossRef] [PubMed]

39. Feng, X.W.; Liu, J.; Harris, T.D.; Hill, S.; Long, J.R. Slow Magnetic Relaxation Induced by a Large Transverse Zero-Field Splitting in a $\mathrm{Mn}^{\mathrm{II}} \mathrm{Re}^{\mathrm{IV}}(\mathrm{CN})_{2}$ Single-Chain Magnet. J. Am. Chem. Soc. 2012, 134, 7521-7529. [CrossRef] [PubMed]

40. Li, Y.-H.; He, W.-R.; Ding, X.-H.; Wang, S.; Cui, L.-F.; Huang, W. Cyanide-bridged assemblies constructed from capped tetracyanometalate building blocks $\left[\mathrm{M}_{\mathrm{A}}(\text { ligand })(\mathrm{CN})_{4}\right]^{1-/ 2-}\left(\mathrm{M}_{\mathrm{A}}=\mathrm{Fe}\right.$ or $\left.\mathrm{Cr}\right)$. Coord. Chem. Rev. 2012, 256, 2795-2815. [CrossRef]

41. Toma, L.M.; Pasan, J.; Catalina, R.-P.; Julve, M.; Lloret, F. $\left[\mathrm{Fe}^{\mathrm{III}}(\mathrm{dmbpy})(\mathrm{CN})_{4}\right]^{-}$: A new building block for designing single-chain magnets. Dalton Trans. 2012, 41, 13716-13726. [CrossRef] [PubMed]

42. Kang, S.; Kanegawa, S.; Sato, O. Slow magnetic relaxation in a 4,2-ribbon like $\mathrm{Fe}^{\mathrm{III}}{ }_{2} \mathrm{Co}^{\mathrm{II}}$ heterobimetallic chain. Dalton Trans. 2012, 41, 13575-13577. [CrossRef] [PubMed]

43. Dong, D.-P.; Liu, T.; Zheng, H.; Zhao, L.; Zhuang, P.-F.; He, C.; Duan, C.-Y. Synthesis, structures and single chain magnet behavior of a cyano-bridged $\left\{\mathrm{Fe}_{2} \mathrm{Cu}\right\}$ chain. Inorg. Chem. Commun. 2012, 24, 153-156. [CrossRef]

44. Chorazy, S.; Nakabayashi, K.; Imoto, K.; Mlynarski, J.; Sieklucka, B.; Ohkoshi, S. Conjunction of Chirality and Slow Magnetic Relaxation in the Supramolecular Network Constructed of Crossed Cyano-Bridged Co ${ }^{\mathrm{II}}-\mathrm{W}^{\mathrm{V}}$ Molecular Chains. J. Am. Chem. Soc. 2012, 134, 16151-16154. [CrossRef] [PubMed]

45. Toma, L.M.; Ruiz-Perez, C.; Pasan, J.; Wernsdorfer, W.; Lloret, F.; Julve, M. Molecular Engineering to Control the Magnetic Interaction between Single-Chain Magnets Assembled in a Two-Dimensional Network. J. Am. Chem. Soc. 2012, 134, 15265-15268. [CrossRef] [PubMed]

46. Bhowmick, I.; Hillard, E.A.; Dechambenoit, P.; Coulon, C.; Harris, T.D.; Clérac, R. A canted antiferromagnetic ordered phase of cyanido-bridged $\mathrm{Mn}^{\mathrm{III}} 2 \mathrm{Re}^{\mathrm{IV}}$ single-chain magnets. Chem. Commun. 2012, 48, 9717-9719. [CrossRef] [PubMed]

47. Ferbinteanu, M.; Miyasaka, H.; Wernsdorfer, W.; Nakata, K.; Sugiura, K.; Yamashita, M.; Coulon, C.; Clérac, R. Single-Chain Magnet $\left(\mathrm{NEt}_{4}\right)\left[\mathrm{Mn}_{2}(5-\mathrm{MeOsalen})_{2} \mathrm{Fe}(\mathrm{CN})_{6}\right]$ Made of $\mathrm{Mn}^{\mathrm{III}}-\mathrm{Fe}^{\mathrm{III}}-\mathrm{Mn}^{\mathrm{III}}$ Trinuclear Single-Molecule Magnet with an ST)9/2 Spin Ground State. J. Am. Chem. Soc. 2005, 127, 3090-3099. [CrossRef] [PubMed] 
48. Miyasaka, H.; Madanbashi, T.; Saitoh, A.; Motokawa, N.; Ishikawa, R.; Yamashita, M.; Bahr, S.; Wernsdorfer, W.; Clérac, R. Cyano-Bridged $\mathrm{Mn}^{\mathrm{III}} \mathrm{M}^{\mathrm{III}}$ Single-Chain Magnets with $\mathrm{M}^{\mathrm{III}}=\mathrm{Co}^{\mathrm{III}}, \mathrm{Fe}^{\mathrm{III}}, \mathrm{Mn}^{\mathrm{III}}$, and Cr ${ }^{\text {III }}$. Chem. Eur. J. 2012, 18, 3942-3954. [CrossRef] [PubMed]

49. Bleuzen, A.; Marvaud, V.; Mathoniere, C.; Sieklucka, B.; Verdaguer, M. Photomagnetism in Clusters and Extended Molecule-Based Magnets. Inorg. Chem. 2009, 48, 3453-3466. [CrossRef] [PubMed]

50. Sieklucka, B.; Podgajny, R.; Przychodzen, P.; Korzeniak, T. Engineering of octacyanometalate-based coordination networks towards functionality. Coord. Chem. Rev. 2005, 249, 2203-2220. [CrossRef]

51. Przychodzen, P.; Korzeniak, T.; Podgajny, R.; Sieklucka, B. Supramolecular coordination networks based on octacyanometalates: From structure to function. Coord. Chem. Rev. 2006, 250, 2234-2260. [CrossRef]

52. Sieklucka, B.; Podgajny, R.; Pinkowicz, D.; Nowicka, B.; Korzeniak, T.; Bałanda, M.; Wasiutyński, T.; Pełka, R.; Makarewicz, M.; Czapla, M.; Rams, M.; et al. Towards high $T_{\mathrm{c}}$ octacyanometalate-based networks. CrystEngComm 2009, 11, 2032-2039. [CrossRef]

53. You, Y.S.; Kim, D.; Do, Y.; Oh, S.J.; Hong, C.S. One-Dimensional Octacyanomolybdate-Based Cu(II)-Mo(V) Bimetallic Assembly with a Novel Rope-Ladder Chain Structure. Inorg. Chem. 2004, 43, 6899-6901. [CrossRef] [PubMed]

54. Yoon, J.H.; Lee, J.W.; Ryu, D.W.; Choi, S.Y.; Yoon, S.W.; Suh, B.J.; Koh, E.K.; Kim, H.C.; Hong, C.S. Cyanide-Bridged $\mathrm{W}^{\mathrm{V}} \mathrm{Mn}^{\mathrm{III}}$ Single-Chain Magnet with Isolated $\mathrm{Mn}^{\mathrm{III}}$ Moieties Exhibiting Two Types of Relaxation Dynamics. Inorg. Chem. 2011, 50, 11306-11308. [CrossRef] [PubMed]

55. Yoo, H.S.; Ko, H.H.; Ryu, D.W.; Lee, J.W.; Yoon, J.H.; Lee, W.R.; Kim, H.C.; Koh, E.K.; Hong, C.S. Octacyanometalate-Based Ferrimagnetic $\mathrm{M}^{\mathrm{V}} \mathrm{Mn}^{\mathrm{III}}(\mathrm{M}=\mathrm{Mo}, \mathrm{W})$ bimetallic chain racemates with slow magnetic relaxations. Inorg. Chem. 2009, 48, 5617-5619. [CrossRef] [PubMed]

56. Yoon, J.H.; Lim, K.S.; Ryu, D.W.; Lee, W.R.; Yoon, S.W.; Suh, B.J.; Hong, C.S. Synthesis, Crystal Structures, and Magnetic Properties of Cyanide-Bridged $\mathrm{W}^{\mathrm{V}} \mathrm{Mn}^{\mathrm{III}}$ Anionic Coordination Polymers Containing Divalent Cationic Moieties: Slow Magnetic Relaxations and Spin Crossover Phenomenon. Inorg. Chem. 2014, 53, 10437-10442. [CrossRef] [PubMed]

57. Kou, H.-Z.; Ni, Z.-H.; Zhou, B.C.; Wang, R.-J.; Kou, H.-Z.; Ni, Z.-H.; Zhou, B.C.; Wang, R.-J. A cyano-bridged molecule-based magnet containing manganese(III) Schiff base and octacyanotungstate(V) building blocks. Inorg. Chem. Commun. 2004, 7, 1150-1153. [CrossRef]

58. Lim, J.H.; Kang, J.S.; Kim, H.C.; Koh, E.K.; Hong, C.S. Synthesis, Crystal Structures, and Magnetic Properties of Cyano-Bridged Honeycomblike Layers $\mathrm{M}^{\mathrm{V}}-\mathrm{Cu}^{\mathrm{II}}(\mathrm{M}=\mathrm{Mo}, \mathrm{W})$ Chelated by a Macrocyclic Ligand. Inorg. Chem. 2006, 45, 7821-2787. [CrossRef] [PubMed]

59. Nowicka, B.; Rams, M.; Stadnicka, K.; Sieklucka, B. Reversible Guest-Induced Magnetic and Structural Single-Crystal-to-Single-Crystal Transformation in Microporous Coordination Network $\left\{[\mathrm{Ni}(\mathrm{cyclam})]_{3}\right.$ $\left.\left[\mathrm{W}(\mathrm{CN})_{8}\right]_{2}\right\}_{n}$. Inorg. Chem. 2007, 46, 8123-8125. [CrossRef] [PubMed]

60. Nowicka, B.; Bałanda, M.; Gaweł, B.; Ćwiak, G.; Budziak, A.; Łasocha, W.; Sieklucka, B. Microporous $\left\{[\mathrm{Ni}(\mathrm{cyclam})]_{3}\left[\mathrm{~W}(\mathrm{CN})_{8}\right]_{2}\right\}_{n}$ affording reversible structural and magnetic conversions. Dalton Trans. 2011, 40, 3067-3073. [CrossRef] [PubMed]

61. Larionova, J.; Clerac, R.; Donnadieu, B.; Willemin, S.; Guerin, C. Synthesis and Structure of a Two-Dimensional Cyano-Bridged Coordination Polymer $[\mathrm{Cu}(\text { cyclam })]_{2}\left[\mathrm{Mo}(\mathrm{CN})_{8}\right] \cdot 10.5 \mathrm{H}_{2} \mathrm{O}(\mathrm{Cyclam}=$ 1,4,8,11-Tetraazacyclodecane). Cryst. Growth Des. 2003, 3, 267-272. [CrossRef]

62. Umeta, Y.; Tokoro, H.; Ozaki, N.; Ohkoshi, S. Room-temperature thermally induced relaxation effect in a two-dimensional cyano-bridged Cu-Mo bimetal assembly and thermodynamic analysis of the relaxation process. AIP Adv. 2013, 3. [CrossRef]

63. Venkatakrishnan, T.S.; Sahoo, S.; Bréfuel, N.; Duhayon, C.; Paulsen, C.; Barra, A.-L.; Ramasesha, S.; Sutter, J.-P. Enhanced ion anisotropy by nonconventional coordination geometry: single-chain magnet behavior for a $\left[\left\{\mathrm{Fe}^{\mathrm{II}} \mathrm{L}\right\}_{2}\left\{\mathrm{Nb}^{\mathrm{IV}}(\mathrm{CN})_{8}\right\}\right]$ helical chain compound designed with heptacoordinate $\mathrm{Fe}^{\mathrm{II}}$. J. Am. Chem. Soc. 2010, 132, 6047-6056. [CrossRef] [PubMed]

64. Sieklucka, B.; Podgajny, R.; Korzeniak, T.; Nowicka, B.; Pinkowicz, D.; Kozieł, M. A decade of octacyanides in polynuclear molecular materials. Eur. J. Inorg. Chem. 2011, 3, 305-326. [CrossRef]

65. Ohkoshi, S.; Hashimoto, K. Photo-magnetic and magneto-optical effects of functionalized metal polycyanides. J. Photochem. Photobiol. C Photochem. Rev. 2001, 2, 71-88. [CrossRef] 
66. Pinkowicz, D.; Pełka, R.; Drath, O.; Nitek, W.; Bałanda, M.; Majcher, A.M.; Poneti, G.; Sieklucka, B. Nature of Magnetic Interactions in $3 \mathrm{D}\left\{\left[\mathrm{M}^{\mathrm{II}}(\text { pyrazole })_{4}\right]_{2}\left[\mathrm{Nb}^{\mathrm{IV}}(\mathrm{CN})_{8}\right] \cdot 4 \mathrm{H}_{2} \mathrm{O}\right\}_{n}(\mathrm{M}=\mathrm{Mn}, \mathrm{Fe}, \mathrm{Co}, \mathrm{Ni})$ Molecular Magnets. Inorg. Chem. 2010, 49, 7565-7576. [CrossRef] [PubMed]

67. Qian, J.; Hu, J.; Zhang, J.; Yoshikawa, H.; Awaga, K.; Zhang, C. Solvent-Induced Assembly of Octacyanometalates-Based Coordination Polymers with Unique afm 1 Topology and Magnetic Properties. Cryst. Growth Des. 2013, 13, 5211-5219. [CrossRef]

68. Pinkowicz, D.; Podgajny, R.; Nitek, W.; Rams, M.; Majcher, A.M.; Nuida, T.; Ohkoshi, S.; Sieklucka, B. Multifunctional Magnetic Molecular $\left\{\left[\mathrm{Mn}^{\mathrm{II}}(\text { urea })_{2}\left(\mathrm{H}_{2} \mathrm{O}\right)\right]_{2}\left[\mathrm{Nb}^{\mathrm{IV}}(\mathrm{CN})_{8}\right]\right\}_{n}$ System: Magnetization-Induced SHG in the Chiral Polymorph. Chem. Mater. 2011, 23, 21-31. [CrossRef]

69. Przychodzeń, P.; Rams, M.; Guyard-Duhayon, C.; Sieklucka, B. Antiferromagnetic coupling through cyano-bridge and $\mathrm{H}$-bonds in $\left[\mathrm{Mn}^{\mathrm{III}}(3-\mathrm{OMesalophen})\left(\mathrm{H}_{2} \mathrm{O}\right)_{2}\right]_{2}\left[\mathrm{Mn}^{\mathrm{III}}(3-\mathrm{OMesalophen})\left(\mathrm{H}_{2} \mathrm{O}\right)\right]$ $\left[\mathrm{W}^{\mathrm{V}}(\mathrm{CN})_{8}\right] \cdot 2 \mathrm{H}_{2} \mathrm{O}$. Inorg. Chem. Commun. 2005, 8, 350-354. [CrossRef]

70. Przychodzeń, P.; Lewiński, K.; Bałanda, M.; Pełka, R.; Rams, M.; Wasiutyński, T.; Guyard-Duhayon, C.; Sieklucka, B. Crystal structures and magnetic properties of two low-dimensional materials constructed from $\left[\mathrm{Mn}^{\mathrm{III}} \text { (salen) } \mathrm{H}_{2} \mathrm{O}\right]^{+}$and $\left[\mathrm{M}(\mathrm{CN})_{8}\right]^{3-/ 4-}(\mathrm{M}=$ Mo or W) precursors. Inorg. Chem. 2004, 43, 2967-2974. [CrossRef] [PubMed]

71. Yang, C.; Wang, Q.-L.; Su, C.-Y.; Hu, L.-N.; Li, L.-C.; Liao, D.-Z. A W(V)-Mn(III) bimetallic assembly built by manganese(III) Schiff-base and octacyanotungstate(V) building blocks: Structure and magnetic property. Inorg. Chem. Commun. 2014, 40, 26-30. [CrossRef]

72. Wang, T.-W.; Wang, J.; Ohkoshi, S.; Song, Y.; You, X.-Z. Manganese(II)-octacyanometallate(V) bimetallic ferrimagnets with $\mathrm{T}_{\mathrm{C}}$ from 41 to $53 \mathrm{~K}$ obtained in acidic media. Inorg. Chem. 2010, 49, 7756-7763. [CrossRef] [PubMed]

73. Ohkoshi, S.; Ikeda, S.; Hozumi, T.; Kashiwagi, T.; Hashimoto, K. Photoinduced magnetization with a high curie temperature and a large coercive field in a cyano-bridged cobalt-tungstate bimetallic assembly. J. Am. Chem. Soc. 2006, 128, 5320-5321. [CrossRef] [PubMed]

74. Mathoniére, C.; Podgajny, R.; Guionneau, P.; Labrugere, C.; Sieklucka, B. Photomagnetism in Cyano-Bridged Hexanuclear Clusters $\left[\mathrm{Mn}^{\mathrm{II}}(\mathrm{bpy})_{2}\right]_{4}\left[\mathrm{M}^{\mathrm{IV}}(\mathrm{CN})_{8}\right]_{2} \cdot x \mathrm{H}_{2} \mathrm{O}(\mathrm{M}=\mathrm{Mo}, x=14$, and $\mathrm{M}=\mathrm{W}, x=9)$. Chem. Mater. 2005, 17, 442-449. [CrossRef]

75. Song, Y.; Zhang, P.; Ren, X.-M.; Shen, X.-F.; Li, Y.-Z.; You, X.-Z. Octacyanometalate-based single-molecule magnets: $\mathrm{Co}^{\mathrm{II}}{ }_{9} \mathrm{M}_{6}^{\mathrm{V}}(\mathrm{M}=\mathrm{W}, \mathrm{Mo})$. J. Am. Chem. Soc. 2005, 127, 3708-3709. [CrossRef] [PubMed]

76. Nowicka, B.; Korzeniak, T.; Stefańczyk, O.; Pinkowicz, D.; Choraży, S.; Podgajny, R.; Sieklucka, B. The impact of ligands upon topology and functionality of octacyanidometallate-based assemblies. Coord. Chem. Rev. 2012, 256, 1946-1971. [CrossRef]

77. Ko, H.H.; Lim, J.H.; Yoo, H.S.; Kang, J.S.; Kim, H.C.; Koh, E.K.; Hong, C.S. Two W ${ }^{\mathrm{V}}-\mathrm{Mn}^{\mathrm{III}}$ bimetallic assemblies built by octacyanotungstate(V) and $\mathrm{Mn}^{\text {III }}$ Schiff bases: molecular structures and a spin-flop transition. Dalton Trans. 2007, 20, 2070-2076. [CrossRef] [PubMed]

78. Choi, S.W.; Ryu, D.W.; Lee, J.W.; Yoon, J.H.; Kim, H.C.; Lee, H.; Cho, B.K.; Hong, C.S. One-dimensional cyanide-bridged $\mathrm{Mn}^{\mathrm{III}} \mathrm{W}^{\mathrm{V}}$ bimetallic complexes: Metamagnetism, spontaneous resolution, and slow magnetic relaxation. Inorg. Chem. 2009, 48, 9066-9068. [CrossRef] [PubMed]

79. Choi, S.W.; Kwak, H.Y.; Yoon, J.H.; Kim, H.C.; Koh, E.K.; Hong, C.S. Intermolecular contact-tuned magnetic nature in one-dimensional $3 \mathrm{~d}-5 \mathrm{~d}$ bimetallic systems: From a metamagnet to a single-chain magnet. Inorg. Chem. 2008, 47, 10214-10216. [CrossRef] [PubMed]

80. Lee, J.W.; Lim, K.S.; Yoon, J.H.; Ryu, D.W.; Koo, B.H.; Koh, E.K.; Hong, C.S. Cyanide-bridged single molecule magnet based on a manganese(III) complex with TTF-fused Schiff base ligand. Sci. China Chem. 2012, 55, 1012-1017. [CrossRef]

81. Lim, K.S.; Hong, C.S. $\left[\mathrm{W}(\mathrm{CN})_{6}(\mathrm{~L})\right]^{1-/ 2-}(\mathrm{L}=$ bidentate ligand $)$ as a useful building unit to construct molecule-based magnetic systems. Dalton Trans. 2013, 42, 14941-14950. [CrossRef] [PubMed]

82. Ishikawa, R.; Nakano, M.; Breedlove, B.K.; Yamashita, M. Syntheses, structures, and magnetic properties of discrete cyano-bridged heterodinuclear complexes composed of $\mathrm{Mn}^{\mathrm{III}}$ (salen)-type complex and $\mathrm{M}^{\mathrm{III}}(\mathrm{CN})_{6}$ anion ( $\left.\mathrm{M}^{\mathrm{III}}=\mathrm{Fe}, \mathrm{Mn}, \mathrm{Cr}\right)$. Polyhedron 2013, 64, 346-351. [CrossRef]

83. Kiernan, P.M.; Griffith, W.P. Studies on transition-metal cyano-complexes. Part I. Octacyanoniobates(III), -niobates(IV), -molybdates(V), and -tungstates(V). J. Chem. Soc. Dalton Trans. 1975, 23, 2489-2494. [CrossRef] 
84. Peresypkina, E.V.; Vostrikova, K.E. $2[\mathrm{Mn}(\text { acacen })]^{+}+1\left[\mathrm{Fe}(\mathrm{CN})_{5} \mathrm{NO}\right]^{2-}$ polynuclear heterobimetallic coordination compounds of different dimensionality in the solid state. Dalton Trans. 2012, 41, 4100-4106. [CrossRef] [PubMed]

85. Rams, M.; Peresypkina, E.V.; Mironov, V.S.; Wernsdorferand, W.; Vostrikova, K.E. Magnetic Relaxation of 1D Coordination Polymers $(\mathrm{X})_{2}\left[\mathrm{Mn}(\right.$ acacen $\left.) \mathrm{Fe}(\mathrm{CN})_{6}\right], \mathrm{X}=\mathrm{Ph}_{4} \mathrm{P}^{+}, \mathrm{Et}_{4} \mathrm{~N}^{+}$. Inorg. Chem. 2014, 53, 10291-10210. [CrossRef] [PubMed]

86. Mironov, V.S.; Chibotaru, L.F.; Ceulemans, A. Exchange interaction in the $\mathrm{YbCrBr}_{9}{ }^{3-}$ mixed dimer: The origin of a strong $\mathrm{Yb}^{3+}-\mathrm{Cr}^{3+}$ exchange anisotropy. Phys. Rev. B 2003, 67, 014424-014428. [CrossRef]

87. Zorina, E.N.; Zauzolkova, N.V.; Sidorov, A.A.; Aleksandrov, G.G.; Lermontov, A.S.; Kiskin, M.A.; Bogomyakov, A.S.; Mironov, V.S.; Novotortsev, V.M.; Eremenko, I.L. Novel polynuclear architectures incorporating $\mathrm{Co}^{2+}$ and $\mathrm{K}^{+}$ions bound by dimethylmalonate anions: Synthesis, structure, and magnetic properties. Inorg. Chim. Acta 2013, 396, 108-118. [CrossRef]

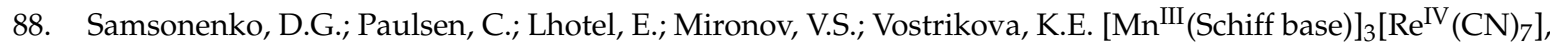
highly anisotropic 3D coordination framework: Synthesis, crystal structure, magnetic investigations, and theoretical analysis. Inorg. Chem. 2014, 53, 10217-10231. [CrossRef] [PubMed]

89. Mironov, V.S. Origin of Dissimilar Single-Molecule Magnet Behavior of Three $\mathrm{Mn}_{2}{ }_{2} \mathrm{Mo}^{\mathrm{III}}$ Complexes Based on $\left[\mathrm{Mo}^{\mathrm{III}}(\mathrm{CN})_{7}\right]^{4-}$ Heptacyanomolybdate: Interplay of $\mathrm{Mo}^{\mathrm{III}}-\mathrm{CN}-\mathrm{Mn}^{\mathrm{II}}$ Anisotropic Exchange Interactions. Inorg. Chem. 2015, 54, 11339-11355. [CrossRef] [PubMed]

90. Schaffer, C.E. A perturbation representation of weak covalent bonding. The symmetry basis for the angular overlap model of the ligand field. Struct. Bond. 1968, 5, 68-95.

91. Tokyo Institute of Technology, Dept. Organic \& Organic Materials Engineering. Atomic Parameters for Extended Huckel Calculation. Available online: http:/ /www.op.titech.ac.jp/lab/mori/EHTB/EHTB 1.html (accessed on 31 January 2017).

92. Lee, S. Electron localization and the structure of transition metal chains. J. Am. Chem. Soc. 1989, 111, 7754-7761. [CrossRef]

93. Seiden, J. Propriétés statiques d'une chaîne isotrope alternée de spins quantiques $1 / 2$ et de spins classiques. J. Phys. Lett. 1983, 44, 947-952. [CrossRef]

94. Carlin, R.L.; Van Duyneveldt, A.J. Magnetic Properties of Transition Metal Compounds; Springer: Berlin, Germany, 1977.

95. Wöhlert, S.; Fic, T.; Tomkowicz, Z.; Ebbinghaus, S.G.; Rams, M.; Haase, W.; Näther, C. Structural and Magnetic Studies of a New Co(II) Thiocyanato Coordination Polymer Showing Slow Magnetic Relaxations and a Metamagnetic Transition. Inorg. Chem. 2013, 52, 12947-12957. [CrossRef] [PubMed]

96. Prosvirin, A.V.; Zhao, H.; Dunbar, K.R. A Mn(III) chain derived from $\mathrm{Mn}_{12}$-acetate that exhibits both glauber dynamics and antiferromangetic ordering regimes. Inorg. Chim. Acta 2012, 389, 118-121. [CrossRef]

97. Mydosh, J.A. Spin Glasses: An Experimental Introduction; Taylor and Francis: London, UK, 1993; p. 67.

98. Cole, K.S.; Cole, R.H. Dispersion and Absorption in Dielectrics I. Alternating Current Characteristics. J. Chem. Phys. 1941, 9, 341. [CrossRef]

99. Sakamoto, F.; Sumiya, T.; Fujita, M.; Tada, T.; Tan, X.S.; Suzuki, E.; Okura, I.; Fujii, Y. T-site selective photocleavage of DNA by cationic Schiff base complex of manganese(III). Chem. Lett. 1998, 11, 1127-1128. [CrossRef]

100. Baadsgaard, H.; Treadwell, W.D. Zur Kenntnis der komplexen Wolframcyanide $\mathrm{K}_{4}\left[\mathrm{~W}(\mathrm{CN})_{8}\right] 2 \mathrm{H}_{2} \mathrm{O}$ und $\mathrm{K}_{3}\left[\mathrm{~W}(\mathrm{CN})_{8}\right] \mathrm{H}_{2} \mathrm{O}$. Helv. Chim. Acta 1955, 38, 1669-1679. [CrossRef]

101. Goodenow, E.L.; Garner, C.S. The Exchange Reaction between Octacyanotungstate(IV) and Octacyanotungstate(V) Ions. J. Am. Chem. Soc. 1955, 77, 5272-5274. [CrossRef]

102. NETZSCH Proteus Thermal Analysis v.4.8.1.; NETZSCH55 Geratebau: Bayern, Germany, 2005.

103. CrysAlisPro; v. 1.171.33.46 (rel. 27-08-2CrysAlis171.NET); Oxford Diffraction Ltd.: Oxford, UK, 2009.

104. De Meulenaar, J.; Tompa, H. The absorption correction in crystal structure analysis. Acta Crystallogr. 1965, 19, 1014-1018. [CrossRef]

105. Cascarano, G.; Altomare, A.; Giacovazzo, C.; Guagliardi, A.; Moliterni, A.G.G.; Siliqi, D.; Burla, M.C.; Polidori, G.; Camalli, M. SIRWARE. Acta Crystallogr. Sect. A 1996, 52, C79. [CrossRef]

106. University of Oxford. Crystallography Program “Crystalsv1461”. Available online: http://www.xtl.ox.ac. uk/crystals.1.html (accessed on 31 January 2017). 
107. Altomare, A.; Burla, M.C.; Camalli, M.; Cascarano, G.L.; Giacovazzo, C.; Guagliardi, A.; Grazia, A.; Moliterni, G.; Polidori, G.; Spagna, R. SIR97: A new tool for crystal structure determination and refinement. J. App. Cryst. 1999, 32, 115-119. [CrossRef]

108. Betteridge, P.W.; Carruthers, J.R.; Cooper, R.I.; Prout, K.; Watkin, D.J. CRYSTALS version 12: Software for guided crystal structure analysis. J. Appl. Cryst. 2003, 36, 1487. [CrossRef] 